\title{
Nitric oxide (NO) stimulates steroidogenesis and folliculogenesis in fish
}

\author{
Vinay Kumar Singh and Bechan Lal \\ Department of Zoology, Fish Endocrinology Laboratory, Institute of Science, Banaras Hindu University, \\ Varanasi, India \\ Correspondence should be addressed to B Lal; Email: lalbhu@yahoo.co.in
}

\begin{abstract}
The present study was undertaken to understand the physiological significance of the existence of nitric oxide synthase (NOS)/nitric oxide (NO) system in fish ovary. For this, two doses of NO donor, sodium nitroprusside (SNP, $25 \mu g$ and $50 \mu g$ ) and NOS inhibitor, $\mathrm{N}$-nitro-L-arginine methyl ester (L-NAME, $50 \mu \mathrm{g}$ and $100 \mu \mathrm{g}$ ) $/ 100 \mathrm{~g}$ body weight were administered during the two reproductive phases of reproductive cycle of the Clarias batrachus. During the late-quiescence phase, high dose of L-NAME decreased the NO, testosterone, $17 \beta$-estradiol, vitellogenin contents in serum and ovary and activities of 5 -ene-3 $\beta$-hydroxysteroid dehydrogenases (3 $\beta$-HSD) and $17 \beta$-hydroxysteroid dehydrogenases (17 $\beta$-HSD) in ovary, whereas higher dose of SNP increased these parameters. L-NAME also reduced oocytes-I but increased perinucleolar oocytes in the ovary, whereas SNP treatment increased the number of advanced oocytes (oocytes-I and II) than the perinucleolar oocytes when compared with control ovary. During the midrecrudescence phase, both doses of SNP increased NO, testosterone, $17 \beta$-estradiol and vitellogenin in serum and ovary; however, L-NAME treatment lowered their levels. The activities of ovarian 3 $\beta-$ HSD and 17 $\beta$-HSD were also stimulated by SNP, but L-NAME suppressed their activities compared to the control. The SNP-treated ovaries were dominated by oocyte-II and III stages, whereas L-NAME-treated ovary revealed more perinucleolar oocytes and oocytes-I and practically no advanced oocytes. Expression of endothelial NOS (eNOS), inducible NOS (iNOS) and neuronal NOS (nNOS) was augmented by the SNP and declined by L-NAME treatments as compared to the control. This study, thus, provides distinct evidence of NO-stimulated steroidogenesis, vitellogenesis and folliculogenesis in fish.

Reproduction (2017) 153 133-146
\end{abstract}

\section{Introduction}

Ovarian folliculogenesis and steroidogenesis are primarily regulated by hormonal secretions of hypothalamo-hypophysial-ovarian axis. Nevertheless, studies on mammals in recent decade provide evidence that some cytokines, growth factors, regulatory peptides and reactive oxygen species, produced locally by the ovarian cells also play a critical role in the regulation of ovarian folliculogenesis and steroidogenesis (Kim et al. 2005, Tesone et al. 2009, see review Lal 2014). These molecules of ovarian origin are reported to be essential for the production of viable eggs. Among these molecules, nitric oxide (NO) has assumed special recognition by researchers due to its versatile physiological roles in reproductive activities. NO, a gaseous signaling molecule, acts as an autocrine or a paracrine factor and is produced by enzymatic action of nitric oxide synthases (NOSs) on arginine. The presence of different NOSs in variety of ovarian cell type has been demonstrated at transcriptional and translational levels in ovary of rat (Zackrisson et al.
1996, Jablonka-Shariff \& Olson 1997, Yamagata et al. 2002), mouse (Nishikimi et al. 2001, Mitchell et al. 2004) and pig (Tao et al. 2004, Kim et al. 2005). In sheep, endothelial nitric oxide synthase (eNOS) mRNA and its peptide change with follicular growth and development of atresia in the ovary (Grazul-Bilska et al. 2006). Endothelial NOS mRNA is also detected in theca and granulosa cells, whereas its protein only in the theca and exclusively in the blood vessels of developing preovulatory and postovulatory follicles (Grazul-Bilska et al. 2006). Kim and coworkers (2005) have shown the presence of neuronal nitric oxide synthase (nNOS) and eNOS immunohistochemically in the surface epithelium, stroma, oocytes, theca cells and endothelial cells of blood vessels in pig. Positive immunoreactions for $\mathrm{nNOS}$ and inducible nitric oxide synthase (iNOS) are also reported in the granulosa cells from multilaminar and antral follicles, but not in unilaminar follicles. iNOS is also detected in the surface epithelium, oocytes and theca of multilaminar and antral follicles (Kim et al. 2005). 
NO is reported as a potential regulator of follicular development, atresia, ovulation, oocyte quality, sexual behavior, pregnancy, infertility and luteal function and so forth in mammals (see review Rosselli et al. 1998, Tamanini et al. 2003, Goud et al. 2005, Skarzynski et al. 2005, see review Kumar et al. 2012). Maul and coworkers (2003) have observed a positive correlation among NO, $17 \beta$-estradiol concentration and follicular volume in human; serum NO level increases with follicular growth and decreases after ovulation in women. It is reported that eNOS-produced NO stimulates ovulation (Mitsube et al. 1999). The importance of NOS-generated $\mathrm{NO}$ in ovulation is also confirmed in NOS-knockout mice (JablonkaShariff \& Olson 1998). Increased vascularization in the theca interna coincides with rapid growth and differentiation of ovarian follicle, while decreased vascularity with follicular atresia (Reynolds et al. 2002, Dubey \& Sharma 2016). In fact, ovarian vascularization increases during the follicular growth in mammals (Mukrakami et al. 1988), particularly after preovulatory LH surge, dilation in vessels around ovarian follicles and blood flow are markedly increased (Kranzfelder et al. 1992). Although the underlying mechanism of this increased vascularization is not fully understood, the involvement of $\mathrm{LH}$-induced intraovarian factors is suggested, and $\mathrm{NO}$ is one of them ( Kranzfelder et al. 1992). It is suggested that NO is necessary for the maintenance of increased ovarian blood flow and completion of normal ovulatory process in rat (Mitsube et al. 2002).

$\mathrm{NO}$ is also shown to modulate ovarian steroidogenesis; most workers have reported NO-induced inhibition in steroids production (Tamanini et al. 2003). Faes et al. (2009), however, have shown that SNP at its higher doses $\left(10^{-3}-10^{-1} \mathrm{M}\right)$ decreases the steroid production, whereas at lower dose, stimulates the $17 \beta$-estradiol production but not progesterone by the cow granulosa cells. NO also uses a number of ways to inhibit ovarian steroid production (Faes et al. 2009).

To the best of author's knowledge, only two studies are available in lower vertebrates including fishes. Tripathi and Krishna (2008) have shown the presence of all isoforms of NOS in the ovary of Heteropneustes fossilis and have indicated that NO plays a role in final oocyte maturation. Recently, authors have also demonstrated season-dependent, cell-specific expression of all forms of NOS in the ovary of catfish, C. batrachus (Singh \& Lal 2015) and have suggested its involvement in estradiol production. Suggestions regarding the involvement of $\mathrm{NO}$ in oogenesis in these fishes and in mammals are largely based on correlative and indirect evidence. Therefore, the present study was undertaken to examine the in vivo and in vitro effects of $\mathrm{NO}$ on steroidogenesis and oogenesis in the catfish, C. batrachus using NO donor and NOS inhibitor compounds.

\section{Materials and methods}

\section{Chemicals}

Anti-iNOS (Cat. No. N7782, 19 amino acid sequence FSYGAKKGSALEEPKATRL of mice iNOS), nNOS (Cat. No. N7280, 21 amino acid sequence RSESIAFIEESKKDADEVFSS of rat nNOS), eNOS (Cat. No. N3893, 21 amino acid sequence RHLRGAVPWAFDPPGPDTPGP of bovine eNOS), vanadium trichloride (Cat. No. 208272), androstenedione (Cat. No. 46033), a NOS inhibitor, L-NAME (Cat. No. N5751) and dehydroepiandrosterone (Cat. No. D063) were purchased from Sigma-Aldrich Chemicals. A nitric oxide donor, SNP (Cat. No. 1.94924.0121) and goat anti-rabbit HRP-tagged secondary antibody (Cat. No. 621140380011730) were procured from Merck. $\beta$-Nicotinamide adenine dinucleotide (Cat. No. 044017) was obtained from SRL (Mumbai, India). Testosterone (Cat. No. DKO002) and 17 $\beta$-estradiol (Cat No. DKO003) ELISA kits were purchased from DiaMetra (Spello, Perugia, Italy). Other chemicals of analytical grade-like salts and solvents were obtained from Merck, Qualigens (Mumbai, India), HiMedia, India.

\section{Fish}

Adult C. batrachus weighing 70-80g were collected from suburbs of Varanasi $\left(25^{\circ} 18^{\prime} \mathrm{N} ; 83^{\circ} 1^{\prime} \mathrm{E}\right)$, India, in the beginning of February and April and were acclimated in cemented tanks of $200 \mathrm{~L}$ water capacity for a fortnight under ambient photoperiod and temperature (late-quiescence phase, February - 11.12-11.26L: 12.48-12.34 D, water temperature $17.2 \pm 1.5^{\circ} \mathrm{C}$ and mid-recrudescence phase, - April - 12.3012.40 L: 11.30-11.20 D, water temperature, $29.1 \pm 2.1^{\circ} \mathrm{C}$ ). Fish were fed with chopped goat liver during acclimation and experimentation period; thereafter, catfish were sorted out in a close weight range i.e. $70-75 \mathrm{~g}$ and were divided into five groups for treatment.

\section{In vivo treatment with $N O$ donor (SNP) and NOS inhibitor (L-NAME)}

Five batches, each of 15 catfish, were injected intramuscularly with two doses of SNP (25 and $50 \mu \mathrm{g})$ and L-NAME (50 and $100 \mu \mathrm{g}$ ) per $100 \mathrm{~g}$ body weight separately, daily for a fortnight during the late-quiescence phase (late February to early March) and mid-recrudescence phase (late April to early May). Control group received only fish saline $(0.65 \% \mathrm{NaCl})$. Doses of SNP and L-NAME were selected based on the pilot experiment, wherein effects of six doses of SNP $(0.1,1,5,10,25$ and $50 \mu \mathrm{g} / 100 \mathrm{~g}$ body weight) and three doses of L-NAME (5, 50 and $100 \mu \mathrm{g} / 100 \mathrm{~g}$ body weight) were observed on circulating $17 \beta$-estradiol and gonadosomatic index (GSI). It was noted that L-NAME at the dose level of 50 and $100 \mu \mathrm{g} / 100 \mathrm{~g}$ body weight suppressed the studied parameters maximally, whereas SNP at 25 and $50 \mu \mathrm{g} / 100 \mathrm{~g}$ body weight induced maximum increase in $17 \beta$-estradiol and GSI.

Fish were anesthetized group-wise by immersing them for 5-10 min in ice-chilled water after $24 \mathrm{~h}$ of the last injection, weighed after proper wiping and blood was collected from 
caudal puncture in glass tubes, separately. Ovaries were removed quickly by dissecting the fish in an aseptic condition in tray and weighed to the nearest gram to calculate GSI using the formula $\mathrm{GSI}=$ (weight of both the ovary in gram/body weight in gram) $\times 100$. For the measurement of activities of $3 \beta$ HSD and $17 \beta-\mathrm{HSD}$, levels of total nitrate-nitrite, $17 \beta$-estradiol, testosterone and vitellogenin, small pieces of ovary were excised and kept in $-70^{\circ} \mathrm{C}$. Some pieces of ovary were also fixed in Bouin's fluid, dehydrated through graded alcohol, cleared in xylene and embedded in paraffin. Sections $(6 \mu \mathrm{m})$ were cut for histological and immunohistochemical studies. Serum was separated by spinning blood at $1006 \mathrm{~g}$ under refrigeration and stored at $-70^{\circ} \mathrm{C}$ until assayed for $17 \beta$-estradiol, testosterone, vitellogenin and total nitrate-nitrite levels. All the experiments of the study were carried out as per the approval of Institutional Animal Ethical Committee of Banaras Hindu University, India (Letter No. F.Sc./IAEC/2016-27/1152).

\section{In vitro treatment with $N O$ donor (SNP) and NOS inhibitor (L-NAME)}

To evaluate the in vitro effect of $\mathrm{NO}$ on steroidogenesis, ovaries of five catfish were rapidly removed and transferred to chilled Medium-199 (HiMedia, Mumbai, India) containing $0.1 \%$ streptomycin, separately, during the mid-recrudescence phase (mid-April). Ovaries were cut into several small pieces in the medium (about 5-6 mg/piece). Such pieces of ovary were taken in fresh media (10-15 mg ovarian fragment/mL media) and pre-incubated for $2 \mathrm{~h}$ at $27 \pm 2^{\circ} \mathrm{C}$ in humidified chamber having $95 \%$ air and $5 \% \mathrm{CO}_{2}$. After this pre-incubation, ovaries were transferred to the culture wells containing the Medium-199 mixed with $0.1 \%$ streptomycin and then incubated with three doses of L-NAME $\left(10^{-5} \mathrm{M}, 10^{-4} \mathrm{M}\right.$ and $\left.10^{-3} \mathrm{M}\right)$ and SNP $\left(10^{-6} \mathrm{M}, 10^{-5} \mathrm{M}\right.$ and $\left.5 \times 10^{-4} \mathrm{M}\right)$ during the mid-recrudescence phase for $36 \mathrm{~h}$. Control incubations were also maintained in which no SNP and L-NAME was added. After the treatment, ovarian fragments and medium were collected and stored at $-70^{\circ} \mathrm{C}$ till the activities of $3 \beta-\mathrm{HSD}$ and $17 \beta-$ HSD and levels of steroids and NO were analyzed. For each treatment, four incubations (using four separate wells) were made for each ovary separately. The process was repeated independently for five ovaries separately on different days.

\section{Measurement of 17ß-estradiol and testosterone}

Ovarian and serum levels of $17 \beta$-estradiol and testosterone were measured using highly sensitive and specific commercial ELISA kits (DiaMetra, Italy) according to the manufacturer's protocol. Before using these kits routinely, dose response inhibition curves of serially diluted serum of the female C. batrachus were examined, which were parallel to the standard curves of $17 \beta$-estradiol and testosterone. Intra-assay and inter-assay precisions were calculated using the serum of the catfish, and coefficient of variations were found to be $5.5 \%$ and $6.4 \%$ for $17 \beta$-estradiol and $6.1 \%$ and $7.2 \%$ for testosterone respectively. Detailed procedures of measurement of $17 \beta$-estradiol and testosterone are described elsewhere (nee Pathak \& Lal 2010, Singh \& Lal 2015).

\section{Determination of activities of $3 \beta-H S D$ and $17 \beta-H S D$ in ovary}

Activity of $3 \beta-\mathrm{HSD}$ was determined by adopting the original method of Wiebe (1976) with slight modifications with regard to $\mathrm{pH}$ of the buffer (from 8.0 to 7.5) and concentrations of $\mathrm{NAD}$ (from $2.7 \mu \mathrm{M}$ to $2.8 \mu \mathrm{M}$ ) and substrate (from $0.23 \mathrm{mM}$ to $0.3 \mathrm{mM}$ ). Detailed protocol is described elsewhere from the author's laboratory (Singh \& Singh 1985). In brief, 10\% ovarian homogenate $(\mathrm{w} / \mathrm{v})$ were prepared in buffered sucrose solution, centrifuged at $1000 \mathrm{~g}$, collected the supernatant, re-centrifuged at $12,000 \mathrm{~g}$ for $30 \mathrm{~min}$ at $4^{\circ} \mathrm{C}$ and collected the supernatant finally for activity assessment. Supernatant $(250 \mu \mathrm{L})$ was added to the sample cuvette containing $0.1 \mathrm{M}$ sodium phosphate buffer $(\mathrm{pH} 7.5), \beta-\mathrm{NAD}$ at saturation concentration $(2.8 \mu \mathrm{M})$ and steroid substrate dehydroepiandrosterone $(0.3 \mathrm{mM})$, dissolved in methanol. The total reaction volume was $3 \mathrm{~mL}$. Cuvettes were pre-incubated at $30^{\circ} \mathrm{C}$ for $5 \mathrm{~min}$, and then the reaction was initiated by adding $\beta$-NAD. Readings were taken after $20 \mathrm{~s}$ of $\beta$-NAD addition at $340 \mathrm{~nm}$, every 15 -s interval for 2 min against blank containing all ingredients except substrate. All assays were run in triplicate for each of the five specimens, separately.

Measurement of $17 \beta$-HSD activity was performed after the original method of Jarabak (1969) with slight modification in using substrate, androstenedione, instead of $17 \beta$-estradiol. Although the detailed procedure of estimation for $17 \beta-\mathrm{HSD}$ activity is described elsewhere from the author's laboratory (Singh \& Singh 1985), the substrate (androstenedione) concentration-response was once again determined in the present study before its routine use.

The reaction system contained steroid substrate androstenedione $(0.3 \mu \mathrm{M}), 0.025 \%$ bovine serum albumin, $440 \mu \mathrm{M}$ sodium pyrophosphate buffer $(\mathrm{pH} 10.2), 1.4 \mu \mathrm{M}$ $\beta$-NAD at saturation concentration and $250 \mu \mathrm{L}$ enzyme preparation. A control containing all components except androstenedione was also run. The total reaction volume was $3 \mathrm{~mL}$. The reaction was started with the addition of $\beta$-NAD. Readings were taken $20 \mathrm{~s}$ after the addition of $\beta$-NAD at $340 \mathrm{~nm}$, every 15 -s interval for $2 \mathrm{~min}$. All assays were run in triplicate using five specimens separately.

\section{Estimation of total nitrate-nitrite}

Serum and ovarian NO was estimated by the method of Miranda and coworkers (2001) with a change in standard $\mathrm{KNO}_{3}$ instead of $\mathrm{NaNO}_{3}$. In brief, serum and $10 \%$ ovarian homogenate $(\mathrm{w} / \mathrm{v})$ were deproteinized by ethanol, centrifuged at $10,000 \mathrm{~g}$ for $15 \mathrm{~min}$ and supernatant was collected. Hundred microliters of each of the graded standard $\mathrm{KNO}_{3}$ solution, serum and ovarian supernatant were taken separately, in triplicate wells of the microtiter plate and added $100 \mu \mathrm{L}$ of vanadium trichloride $\left(\mathrm{VCl}_{3}\right)$ solution $\left(0.8 \% \mathrm{VCl}_{3}\right.$ in $\left.1 \mathrm{M} \mathrm{HCl}\right)$ in each well, and then rapidly added the Griess reagent $(50 \mu \mathrm{L}$ $0.1 \%$ NEDD in distilled water and $50 \mu \mathrm{L} 2 \%$ sulphonilamide in $5 \% \mathrm{HCl}$ ), incubated at $37^{\circ} \mathrm{C}$ for $30-45 \mathrm{~min}$, and absorbance was measured at $540 \mathrm{~nm}$. Standard curve for total nitrate-nitrite was plotted using absorbance against $\mathrm{KNO}_{3}$ concentrations. The concentration of total nitrate and nitrite in serum and ovarian samples were intrapolated from the standard curve. 

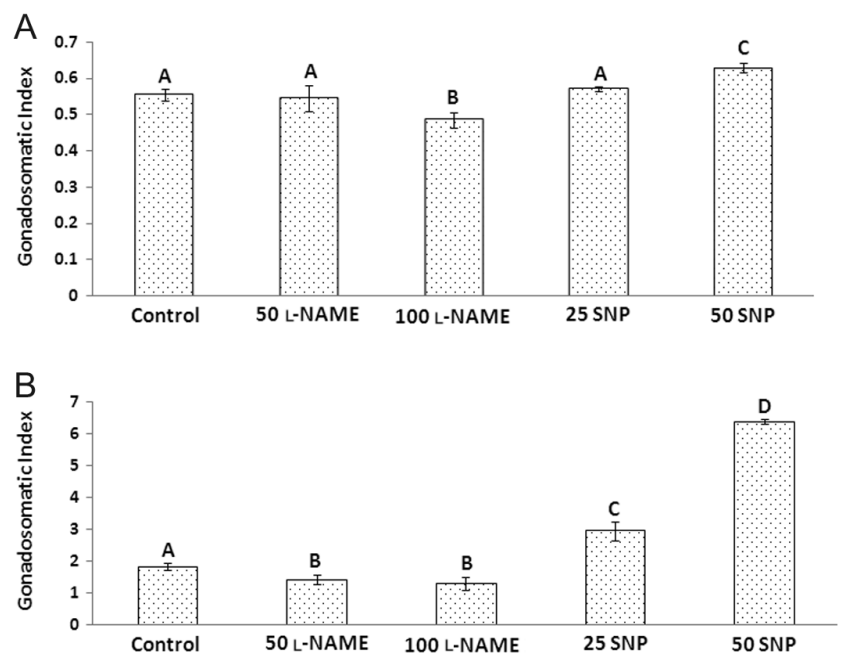

Figure 1 Effect of different doses of L-NAME $(50 \mu \mathrm{g}$ and $100 \mu \mathrm{g})$ and SNP $(25 \mu \mathrm{g}$ and $50 \mu \mathrm{g})$ per $100 \mathrm{gb} . w \mathrm{t}$. on the gonadosomatic index of $C$. batrachus during the late-quiescence $(\mathrm{A})$ and mid-recrudescence phases (B). Each bar represents mean \pm S.E.M. $(n=5)$. Means bearing same superscripts do not differ from each other, whereas bearing different superscripts are different from each other statistically at $P<0.05$ (Duncan's multiple range test). The $F$ values after ANOVA of data related to GSI in response to L-NAME treatment during the late-quiescence phase was 6.762 , whereas 10.676 during the mid-recrudescence phase, likewise in case of SNP treatment $F$ values were 30.535 during the late-quiescence phase and 549.908 during mid-recrudescence phase.

\section{Determination of vitellogenin}

Concentration of serum and ovarian vitellogenin (Vg1) were determined by homologous ELISA for catfish (C. batrachus) vitellogenin (catfish-Vg1) in the laboratory of Prof $\mathrm{P}$ Nath, Department of Zoology, Vivsa-Bharati University, Santiniketan, India, adopting original method of
Nath and Maitra (2001). Purified vitellogenin, its specific antibody and other reagents were provided by Prof Nath. Details of the procedure are described elsewhere (Nath \& Maitra 2001, Maitra et al. 2007). In brief, microtiter plates were coated with $125 \mathrm{ng} /$ well with catfish-Vg1 in $200 \mu \mathrm{L}$ of carbonate-bicarbonate buffer $(\mathrm{pH}$ 9.6) and with buffer only for non-specific binding for overnight at $4^{\circ} \mathrm{C}$. Next day morning, wells were flicked and washed with PBS-Tween-20 (PBS-T, pH 7.4) and blocked with $200 \mu \mathrm{L} /$ well of $1 \%$ BSA. Two hundred microliters of serially diluted catfish-Vg1 $(10,000-156 \mathrm{ng} / \mathrm{mL})$, serum and $10 \%$ ovarian homogenate $(\mathrm{w} / \mathrm{v})$ samples (diluted 1:100 or more in 0.01M PBS, $\mathrm{pH}$ 7.4) were incubated with equal volume of anti-Vg1 (diluted $1: 40,000$ in $0.01 \mathrm{M} \mathrm{PBS}$ ) in micro-centrifuge tubes, separately, for $14 \mathrm{~h}$ at $4^{\circ} \mathrm{C}$. Assay buffer $(200 \mu \mathrm{L})$ was also incubated with $200 \mu \mathrm{L}$ of diluted anti-Vg1 for $\mathrm{B}_{0}$ and with $200 \mu \mathrm{L}$ of $1 \%$ BSA for non-specific binding (NSB). Two hundred microliters of these pre-incubated samples were then transferred in triplicate to the Vg1-coated microplates and incubated for overnight at $4^{\circ} \mathrm{C}$. Then, the contents of microtiter plate were flicked and washed with PBS-T thrice. The immobilized Vg-antibody complex was detected with goat anti-rabbit IgG conjugated to peroxidase antiperoxidase (diluted 1:4000 in PBS-BSA). Color was developed by adding ortho-phenylene diamine $(20 \mathrm{mg}$ OPD in $50 \mathrm{~mL}$ of $0.1 \mathrm{M}$ citrate-phosphate buffer, $\mathrm{pH} 5.0$, containing $6 \mu \mathrm{L}$ of hydrogen peroxide) to the plate $(200 \mu \mathrm{L} /$ well $)$ and incubated for $30 \mathrm{~min}$ in darkness at room temperature. Reaction was stopped with $1 \mathrm{M} \mathrm{H}_{2} \mathrm{SO}_{4}$ $(50 \mu \mathrm{L} /$ well) and read at $492 \mathrm{~nm}$ on Anthos 2001 microplate reader (Gemini BV Laboratory, Apeldoorn, The Netherlands). Under these conditions, the intra- and inter-assay coefficients of variance were $2.21 \%$ and $7.95 \%(n=6)$ respectively.

\section{Morphological analyses of ovary}

For histological study, paraffin sections of ovaries collected from treated and control fish were de-parafinized, hydrated
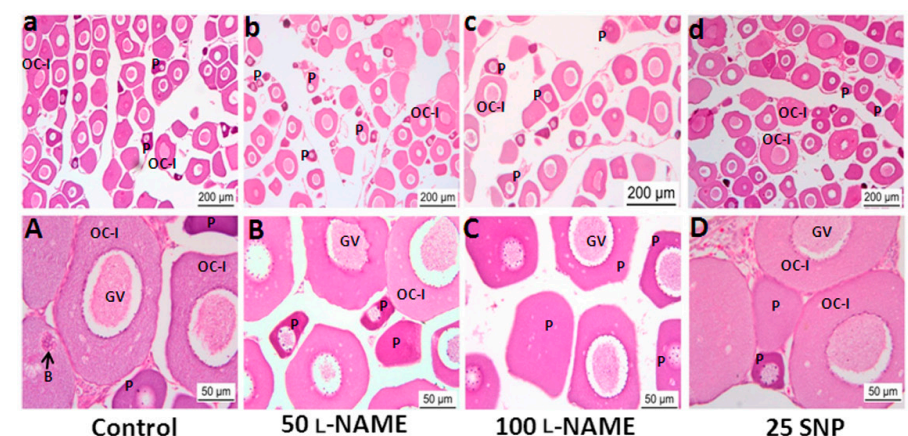

25 SNP

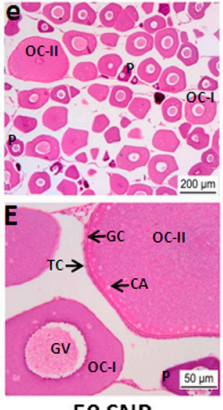

50 SNP
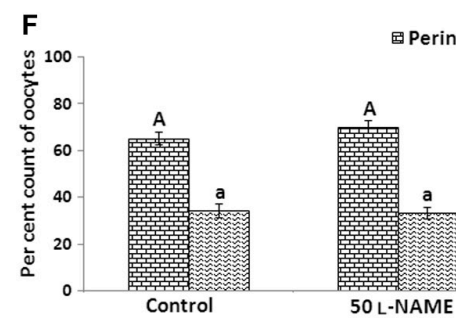

Perinucleolar oocytes

@ Oocytes-1

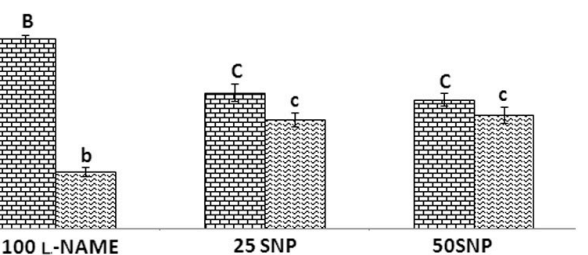

Figure 2 Representative images of hematoxylin/eosin-stained transverse sections of the late-quiescent ovaries of $C$. batrachus after treatments with L-NAME $(50 \mu \mathrm{g}$ and $100 \mu \mathrm{g})$ and SNP $(25 \mu \mathrm{g}$ and $50 \mu \mathrm{g})$ per $100 \mathrm{gb}$.wt. Photographs were taken at $10 \times(\mathrm{a}, \mathrm{b}, \mathrm{c}, \mathrm{d}$ and $\mathrm{e})$ and at $40 \times(\mathrm{A}, \mathrm{B}, \mathrm{C}, \mathrm{D}$ and $\mathrm{E}$ ). Oocyte counts are presented in figure $\mathrm{F}$ in term of percentage. Means bearing same superscripts do not differ from each other, whereas bearing different superscripts are different from each other statistically at $P<0.05$ (Duncan's multiple range test). A, B and $C$ are used for perinucleolar oocytes and a, b and c for oocytes-I. Note: Perinucleolar oocytes (P), Oocytes-I (OC-I), Oocytes-II (OC-II), Germinal vesicle (GV), Cortical Alveoli (CA), Balbiani Body (B), Granulosa Cell (GC), Thecal Cell (TC). The $F$ values after ANOVA of data related to perinucleolar and oocyte I counts in response to L-NAME treatment during the late-quiescence phase were 35.139 and 16.185 , whereas 8.699 and 20.783 after SNP treatment. 

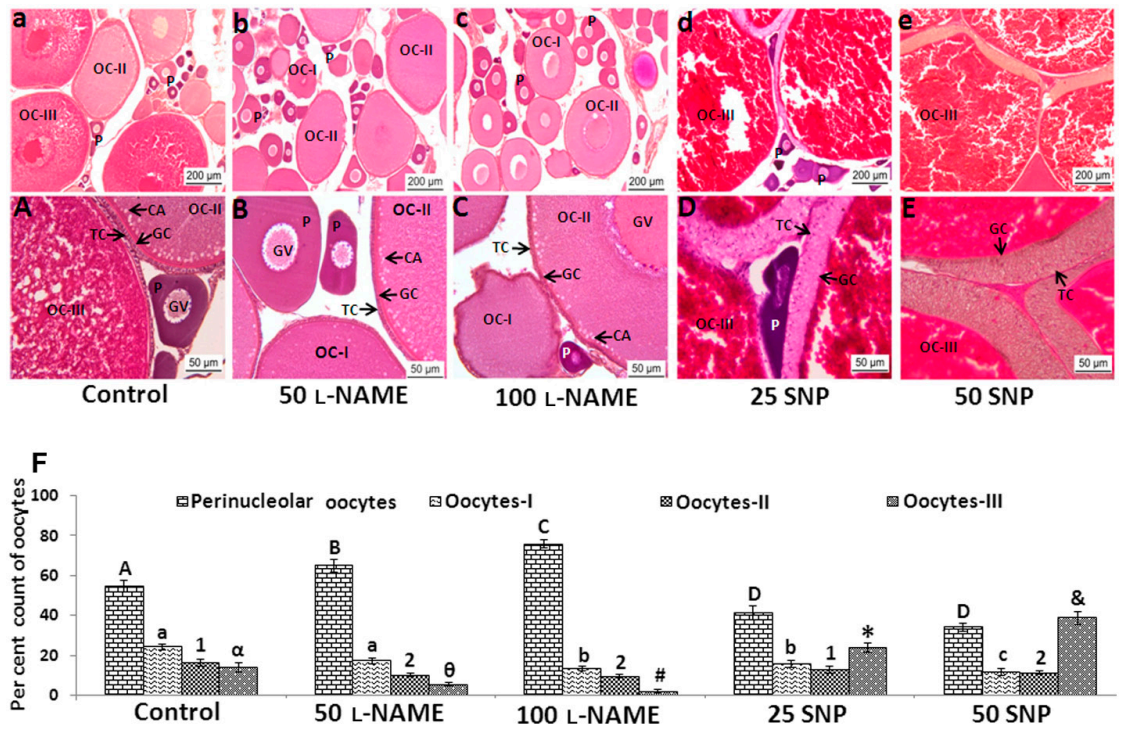

冈ocytes-II

Oocytes-III

50 SNP
Figure 3 Representative images of hematoxylin/ eosin-stained transverse sections of midrecrudescence ovaries of $C$. batrachus after treatments with L-NAME $(50 \mu \mathrm{g}$ and $100 \mu \mathrm{g})$ and SNP $(25 \mu \mathrm{g}$ and $50 \mu \mathrm{g})$ per $100 \mathrm{gb} . w \mathrm{t}$. Photographs were taken at $10 \times(\mathrm{a}, \mathrm{b}, \mathrm{c}, \mathrm{d}$ and $\mathrm{e})$ and at $40 \times$ (A, B, C, D and E). Oocyte counts are presented in figure $\mathrm{F}$ in term of percentage. Means bearing same superscripts do not differ from each other, whereas bearing different superscripts are different from each other statistically at $P<0.05$ (Duncan's multiple range test). Superscripts A, B, $C$ and $\mathrm{D}$ are used for perinucleolar oocytes, whereas $\mathrm{a}, \mathrm{b}$ and $\mathrm{c}$ for oocytes-I, 1 and 2 for oocytes-II and $\alpha, \theta, *, \#$, and for oocytes-III. Note: Perinucleolar oocytes (P), Oocytes-I (OC-I), Oocytes-II (OC-II), Oocytes-III (OC-III), Germinal vesicle (GV), Cortical Alveoli (CA), Granulosa Cell (GC), Thecal Cell (TC). The $F$ values after ANOVA of data related to perinucleolar, oocyte I, II and III counts in response to L-NAME treatment during the mid-quiescence phase were $47.120,51.319$, 30.855 and 54.815 , whereas $47.349,49.128$, 9.802 and 75.671 , respectively after SNP treatment. gradually through graded ethanol to triple distilled water and stained finally with Ehrlich hematoxylin and eosin. After staining, sections were dehydrated sequentially in graded ethanol and were mounted with DPX and cover glass. Images were captured at $10 \times$ and $40 \times$ by Leica DM2000 camera attached microscope. To count different stages of oocytes, 10× magnified images were opened with Motic Images Plus V2.0 Software. After proper calibration of images, a field of $10 \mathrm{~mm}^{2}$ area were selected randomly and perinuclear oocytes, oocytes-I, II and III were counted manually for three such fields from several ovarian sections belonging to the ovaries of five fish, separately. Finally counts were normalized in terms of percent and expressed as mean \pm S.E.M.

Fish ovaries, being asynchronous mostly, contain oocytes of different developmental stages in the ovarian stroma. The relative proportion of advanced oocytes increases with the advancement of ovarian development. Different oocytes were categorized based on specific features of each stage and counted as per Sundararaj and Sehgal (1970). The perinucleolar oocytes are very small oocytes with large germinal vesicle showing multiple nucleoli at its periphery and were surrounded by very little cytoplasm. It also exhibited a juxtanuclear mass termed as Balbiani body or yolk nucleus. Oocytes-I, non-yolky oocytes, were differentiated by its relatively larger size over perinucleolar oocytes with big germinal vesicle, substantial cytoplasm and surrounded by somatic cells. Oocyte-II, an early yolky oocyte, was distinguished from oocytes-I by its further enlarged size with distinct cortical alveoli beneath the oocyte membrane. It was enveloped by single granulosa cell layer and thecal layers. Oocytes III, more developed oocytes, were full of yolk granules and had fully developed granulosa and thecal layers.
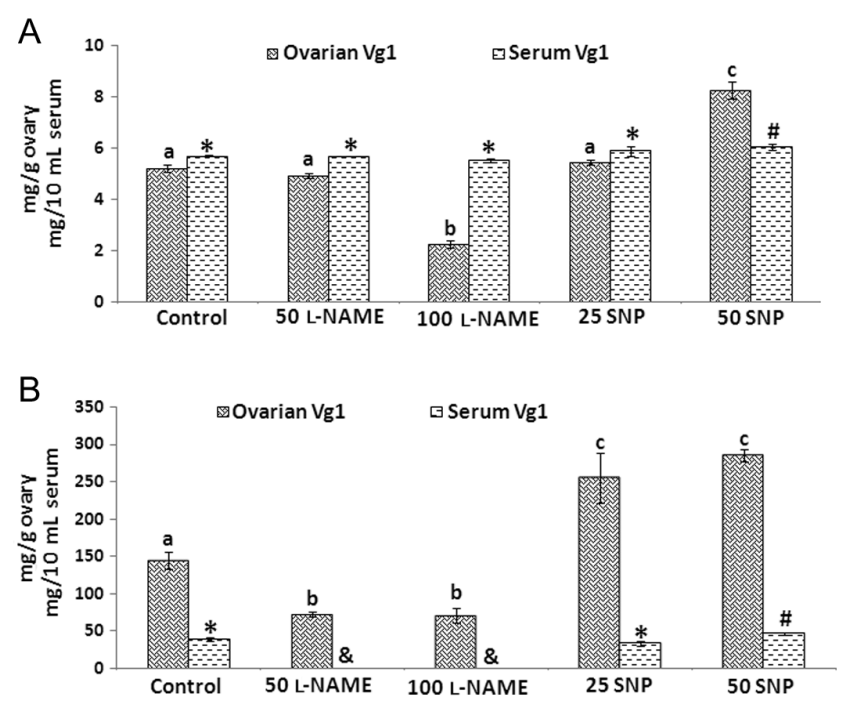

Figure 4 Effect of different doses of L-NAME $(50 \mu \mathrm{g}$ and $100 \mu \mathrm{g})$ and SNP $(25 \mu \mathrm{g}$ and $50 \mu \mathrm{g})$ per $100 \mathrm{gb} . w \mathrm{t}$. on vitellogenin 1 concentration in ovary and serum of $C$. batrachus during the late-quiescence (A) and mid-recrudescence phases (B). Each bar represents mean \pm S.E.M. $(n=5)$. Means bearing same superscripts do not differ from each other, whereas bearing different superscripts are different from each other statistically at $P<0.05$ (Duncan's multiple range test).

Superscripts a, b and c are used for ovarian Vg1 whereas \&, * and \# for serum $V g 1$. The $F$ values after ANOVA of data related to ovarian vitellogenin 1 and serum vitellogenin 1 in response to L-NAME treatment during the late-quiescence phase were 493.897 and 16.601, whereas 69.321 and 1.312 during the mid-recrudescence phase; likewise, in case of SNP treatment, $F$ values were 213.996 and 5.537 during the late-quiescence phase and 40.603 and 23.564 during the mid-recrudescence phase. 

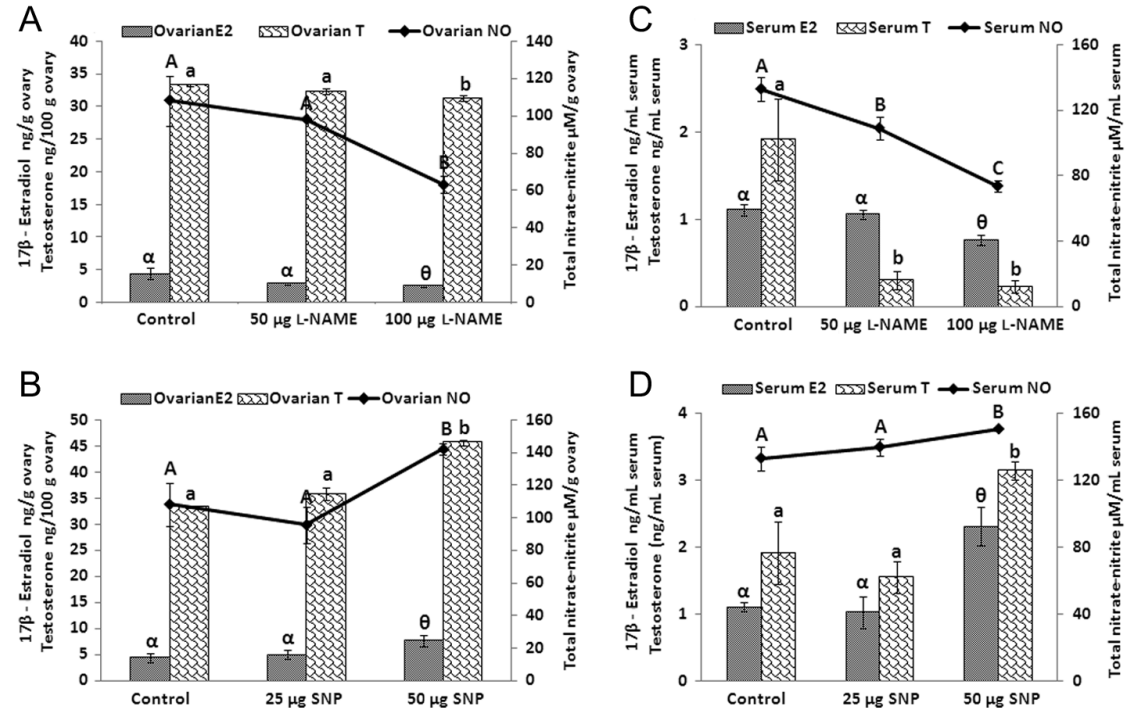

Figure 5 Effect of different doses of L-NAME $(50 \mu \mathrm{g}$ and $100 \mu \mathrm{g})$ and $\mathrm{SNP}(25 \mu \mathrm{g}$ and $50 \mu \mathrm{g})$ per 100 gb.wt. on ovarian $17 \beta$-estradiol, testosterone and $\mathrm{NO}$ levels (A and $\mathrm{B}$ ) and serum (C and $D$ ) in $C$. batrachus during the late-quiescence phase. Each bar represents mean \pm S.E.M. $(n=5)$. Means bearing same superscripts do not differ from each other, whereas bearing different superscripts are different from each other statistically at $P<0.05$ (Duncan's multiple range test). Superscripts A, B and C are used for NO while $\mathrm{a}$ and $\mathrm{b}$ for testosterone, and $\alpha$ and $\theta$ for $17 \beta$-estradiol. The $F$ value after ANOVA of the data related to serum $T$ in response to L-NAME treatment was 195.482 while 30.564 and 79.295 for serum E2 and NO respectively; while for ovarian T, E2 and NO, $F$ values were $25.659,11.849$ and 27.988 respectively. Similarly in case of SNP treatment, $F$ values for serum T, E2 and NO were 50.978, 35.337 and 10.393 and ovarian T, E2 and NO $86.396,10.380$ and 18.582 , respectively.

\section{Immunohistochemical localization of $n N O S$, iNOS and eNOS in ovary}

Paraffin sections of ovary, collected from the treated and control fish of the mid-recrudescence phase were de-paraffinized, hydrated gradually through graded ethanol to distilled water and finally washed with PBS $(0.01 \mathrm{M}$, $\mathrm{pH}$ 7.4) thrice. Then, endogenous peroxidase activity were quenched in 1:40 $\mathrm{H}_{2} \mathrm{O}_{2}$ in methanol for $30 \mathrm{~min}$ and washed in PBS. These sections were then processed for immunohistochemical localization of different NOSs through HRP-conjugated antibody method. Details of antibodies used against different NOS and the protocol for immunolocalization are described elsewhere by the authors (nee Pathak \& Lal 2010, Singh \& Lal 2015). Specificity of antibodies was validated through immunoblotting before their routine use. Proteins of the mice brain for nNOS, mice uterus for eNOS, macrophages for iNOS and catfish ovary were separated on non-reducing SDS-PAGE (7\%) and then electro-transferred on polyvinylidene difluoride (PVDF) membrane along with appropriate protein molecular weight markers and incubated them separately, with corresponding primary antibodies and finally with secondary antibody. Blots were developed with ECL kit on X-ray film.

For immunolocalization, briefly, the ovarian sections were first incubated with $5 \%$ normal goat serum for $1 \mathrm{~h}$ at room temperature in a moist chamber. Then, it was drained and incubated with 1:600 diluted anti-eNOS, anti-iNOS and
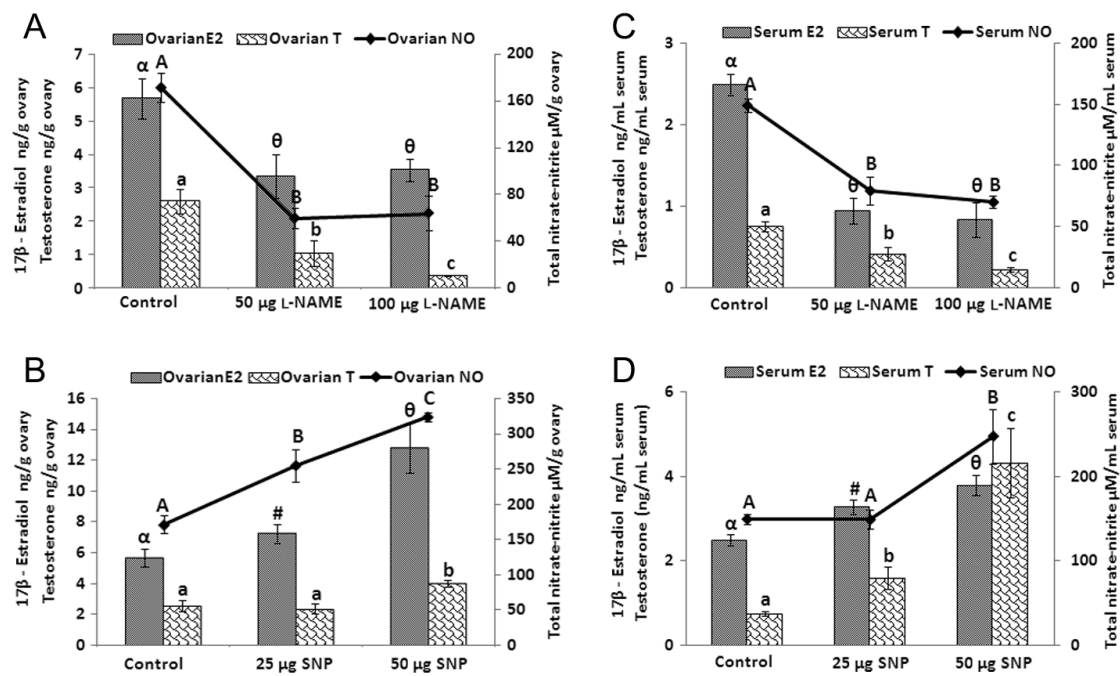

Figure 6 Effect of different doses of L-NAME $(50 \mu \mathrm{g}$ and $100 \mu \mathrm{g})$ and SNP $(25 \mu \mathrm{g}$ and $50 \mu \mathrm{g})$ per $100 \mathrm{gb} . w t$. on ovarian testosterone, $17 \beta$-estradiol and NO levels in ovary (A and $\mathrm{B})$ and serum (C and D) in C. batrachus during the mid-recrudescence phase. Each bar represents mean \pm S.E.M. $(n=5)$. Means bearing same superscripts do not differ from each other while bearing different superscripts are different from each other statistically at $P<0.05$ (Duncan's multiple range test). Superscripts A, B and C are used for NO while $\mathrm{a}, \mathrm{b}$ and $\mathrm{c}$ for testosterone, and $\alpha$, \# and $\theta$ for $17 \beta$-estradiol. The $F$ value after ANOVA of data related to serum $T$ in response to $\mathrm{L}-\mathrm{NAME}$ treatment was 61.579 while 96.664 and 101.677 for serum E2 and NO respectively; likewise for ovarian T, E2 and NO, F values were 48.003, 18.330 and 87.790 respectively. Similarly in case of SNP treatment, $F$ values for serum T, E2 and NO were 47.319, 40.365 and 26.602 and ovarian T, E2 and NO 28.939, 41.287 and 81.227 , respectively. 

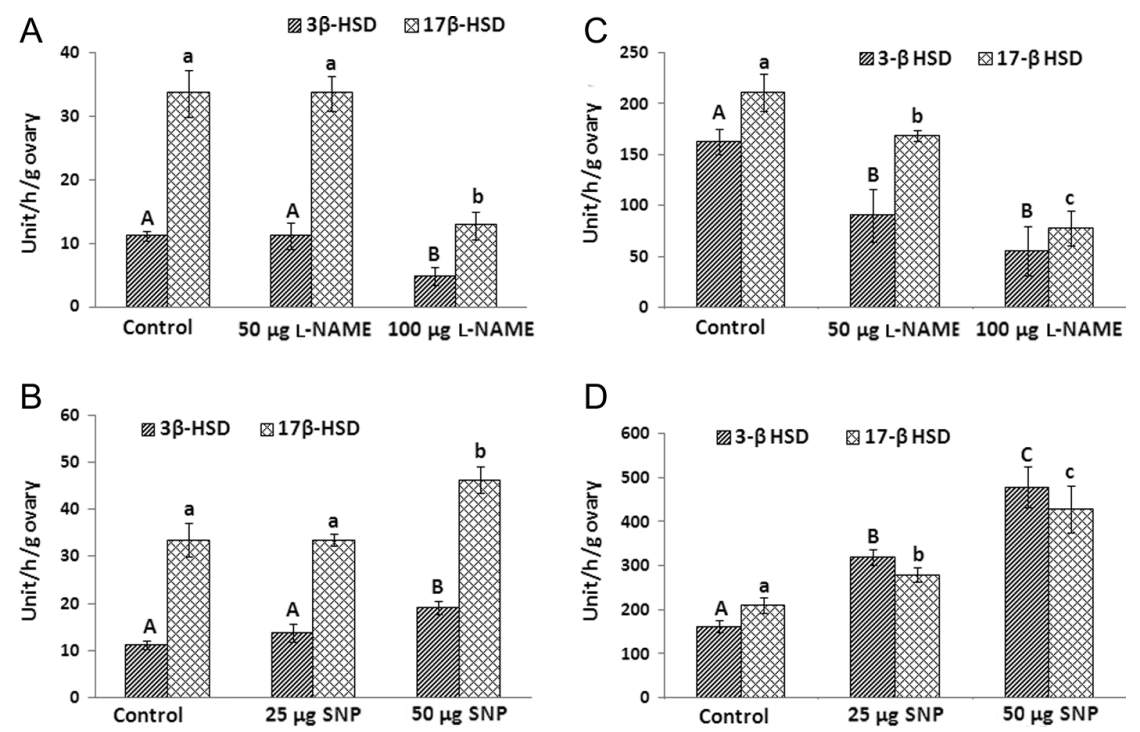

Figure 7 Effect of different doses of L-NAME $(50 \mu \mathrm{g}$ and $100 \mu \mathrm{g})$ and SNP $(25 \mu \mathrm{g}$ and $50 \mu \mathrm{g})$ per $100 \mathrm{gb} . w \mathrm{t}$. on activity of $3 \beta-\mathrm{HSD}$ and $17 \beta-$ HSD during the late-quiescence (A and $B$ ) and the mid-recrudescence phase (C and $D)$ in C. batrachus. Each bar represents mean \pm S.E.M. $(n=5)$. Means bearing same superscripts do not differ from each other, whereas mean bearing different superscripts are different from each other statistically at $P<0.05$ (Duncan's multiple range test). Superscripts $A$ and $B$ are used for $3 \beta-$ HSD and $a, b$ and $c$ for $17 \beta-$ HSD. The $F$ values after ANOVA of data related to ovarian $3 \beta-\mathrm{HSD}$ and $17 \beta-\mathrm{HSD}$ in response to L-NAME treatment during the late-quiescence phase were 19.394 and 56.333, whereas 21.410 and 70.342 respectively during the mid-recrudescence phase. Similarly, in response to SNP treatment, $F$ values were 25.622 and 23.063 during the late-quiescence phase and 94.174 and 34.650 during the mid-recrudescence phase.
anti-nNOS, separately, for overnight at $4{ }^{\circ} \mathrm{C}$. Next morning, sections were drained, washed in PBS, followed by their incubation with HRP-tagged secondary antibody (dilution $1: 100$ ) for $3.5 \mathrm{~h}$ at room temperature, thereafter washed with PBS. Then sections were subjected to the chromogen 0.06\% 3-3'diaminobenzidine tetrahydrochloride hydrate (DAB) with $\mathrm{H}_{2} \mathrm{O}_{2}$ and kept in darkness for 5-10 min to develop color. Reaction was stopped by dipping sections in PBS, dehydrated and mounted with glass cover and DPX. In corresponding negative control sections, primary antibodies were replaced by PBS. The images were captured at $40 \times$ by Leica DM2000 camera attached microscope. The immunoreactivity was analyzed by spot densitometry tool, Alpha EaseFC software (Alpha Innotech Corp., CA, USA). Integrated density values (IDV) in term of arbitrary unit were calculated in ovarian sections for NOSs expression after deducting the value of negative control.

\section{Statistical analyses}

Data on concentrations of $17 \beta$-estradiol, testosterone, vitellogenin, total nitrate-nitrite and activities of $3 \beta-\mathrm{HSD}$ and $17 \beta-$ HSD and GSI are presented as mean \pm S.E.M. $(n=5)$. Ovarian testosterone is expressed as ng/100 g ovary during the late-quiescence phase and ng/g ovary and ng/10g ovarian fragments) during the mid-recrudescence phase, whereas $17 \beta$-estradiol in terms of ng/g ovary. The circulating levels of $17 \beta$-estradiol and testosterone are presented as $\mathrm{ng} / \mathrm{mL}$ serum. The total nitrate-nitrite is given as $\mu \mathrm{M} / \mathrm{g}$ ovary and $\mu \mathrm{M} / \mathrm{mL}$ serum. The activities of $3 \beta-\mathrm{HSD}$ and $17 \beta-\mathrm{HSD}$ are expressed as unit/h/g ovary. Intensity of NOSs expression is presented as IDV. Data were analyzed through ANOVA followed by Duncan's multiple range test $(P<0.05)$. For in vitro studies, the mean for each treatment was calculated using data of four wells for each ovary, separately. Then after means of five separate ovaries, taken for study, were used to calculate final mean \pm SEM for presentation and ANOVA analyses supplemented with post hoc tests.

\section{Results}

\section{Effects of SNP and L-NAME on gonadosomatic index (GSI)}

GSI was suppressed by the L-NAME but was elevated by SNP treatments at their higher dose levels during the
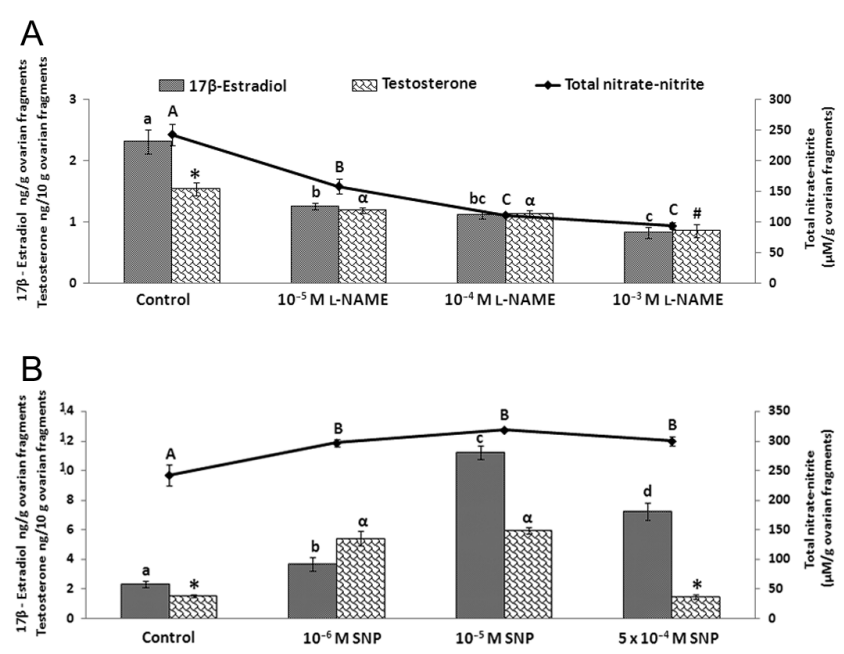

Figure 8 In vitro effect of different doses of L-NAME $\left(10^{-5} \mathrm{M}, 10^{-4} \mathrm{M}\right.$ and $\left.10^{-3} \mathrm{M}\right)$ and $\mathrm{SNP}\left(10^{-6} \mathrm{M}, 10^{-5} \mathrm{M}\right.$ and $\left.5 \times 10^{-4} \mathrm{M}\right)$ on testosterone, $17 \beta$-estradiol and NO levels in ovarian fragments of $C$. batrachus during the mid-recrudescence phase. Each bar represents mean \pm S.E.M. $(n=4)$. Means bearing same superscripts do not differ from each other, whereas bearing different superscripts are different from each other statistically at $P<0.05$ (Duncan's multiple range test). Superscripts A, B and C are used for NO while a, b, c and $d$ for $17 \beta$-estradiol, and $*, \alpha$ and \# for testosterone. The $F$ value after ANOVA of data related to $T$ in ovarian fragments in response to L-NAME treatment was 12.402 while 31.664 and 36.126 for $17 \beta$-estradiol and NO respectively. Similarly, $F$ values for T, $17 \beta$-estradiol and NO in ovarian fragments after SNP treatment were 75.993, 78.303 and 10.275, respectively. 

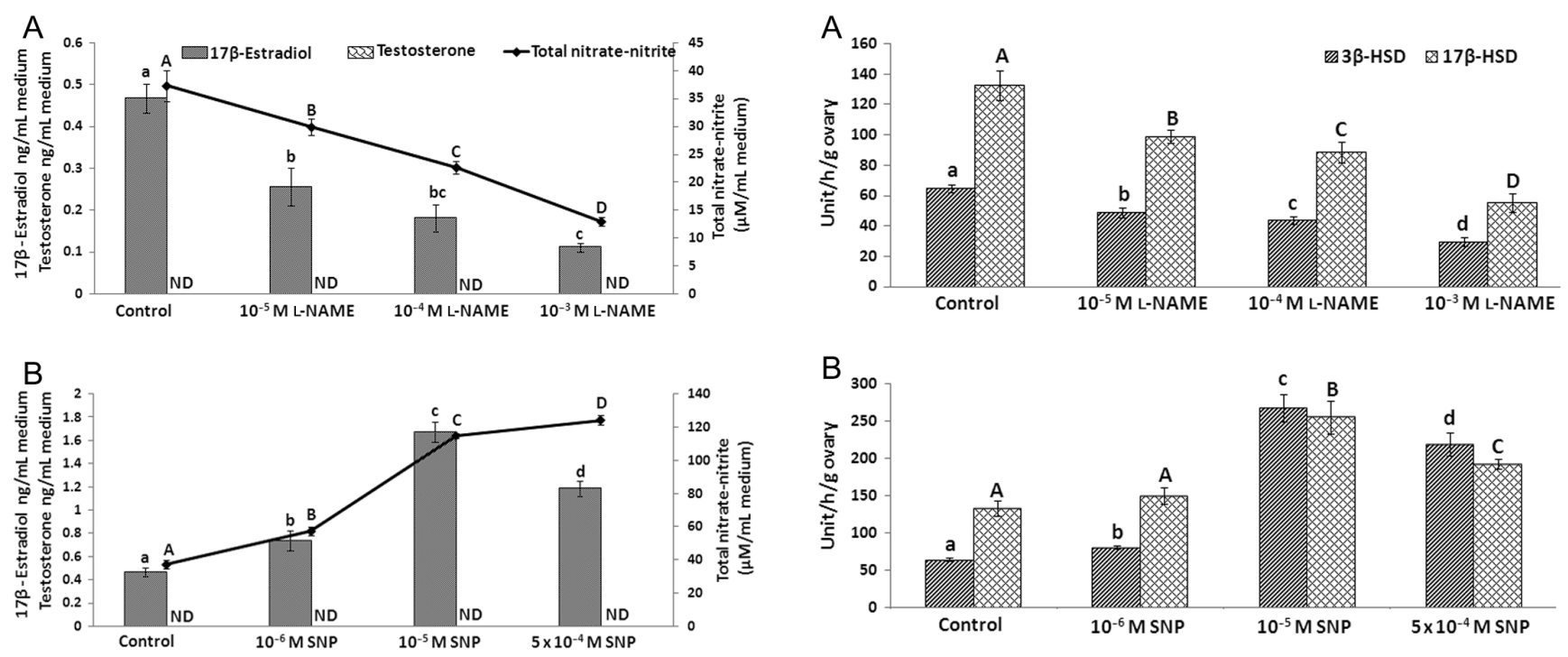

Figure 9 In vitro effect of different doses of L-NAME $\left(10^{-5} \mathrm{M}, 10^{-4} \mathrm{M}\right.$ and $\left.10^{-3} \mathrm{M}\right)$ and $\mathrm{SNP}\left(10^{-6} \mathrm{M}, 10^{-5} \mathrm{M}\right.$ and $\left.5 \times 10^{-4} \mathrm{M}\right)$ on testosterone, $17 \beta$-estradiol and $\mathrm{NO}$ levels in medium after incubation of ovarian fragments of $C$. batrachus during the mid-recrudescence phase. Each bar represents mean \pm S.E.M. $(n=4)$. Means bearing same superscripts do not differ from each other while bearing different superscripts are different from each other statistically at $P<0.05$ (Duncan's multiple range test). Superscripts $A, B, C$ and D are used for NO while a, b, c and $d$ for $17 \beta$-estradiol. The $F$ value after ANOVA of data related to $17 \beta$-estradiol in media in response to L-NAME treatment was 20.974 while 37.141 for NO. Similarly, $F$ values for $17 \beta$-estradiol and $N O$ in media after SNP treatment were 54.433 and 301.088 respectively.

late-quiescent phase (Fig. 1A). However, during the midrecrudescence phase, both doses of L-NAME decreased and SNP increased GSI significantly $(P<0.05)$ (Fig. 1B).

\section{Effects of SNP and L-NAME on ovarian histology}

During the late-quiescent phase, the ovaries were relatively small and contained only perinucleolar oocytes and oocyte-I in the ovigerous folds (Fig. 2a and A). Though the ovary treated with lower dose of L-NAME did not change the ovarian morphology in general (Fig. $2 \mathrm{~b}$ and $\mathrm{B}$ ), ovary treated with higher dose of L-NAME revealed relatively more perinucleolar oocytes and less oocytes-I (Fig. 2C, C and F) as compared to the control ovary. However, SNP at both dose levels increased the oocytes-I and decreased the number of perinucleolar oocytes marginally (Fig. 2d, D, e, E and F) in comparison to the control. Occasional oocytes-II was also observed in the ovary treated with higher dose of SNP (Fig. 2e, E).

In the mid-recrudescence phase, ovary became large and was filled with perinucleolar oocytes, oocytes-I and II and occasional oocytes III. The ovary of this phase was characterized by the presence of relatively large number of oocytes-I and II (Fig. 3a and A) as compared to the perinucleolar oocytes when compared to latequiescent ovary (Fig. 2a and A). Effects of NO-related drugs were more pronounced during this phase than the

Figure 10 In vitro effect of different doses of L-NAME $\left(10^{-5} \mathrm{M}, 10^{-4} \mathrm{M}\right.$ and $\left.10^{-3} \mathrm{M}\right)$ and $\mathrm{SNP}\left(10^{-6} \mathrm{M}, 10^{-5} \mathrm{M}\right.$ and $\left.5 \times 10^{-4} \mathrm{M}\right)$ on activities of $3 \beta-\mathrm{HSD}$ and $17 \beta-\mathrm{HSD}$ in ovarian fragments of $C$. batrachus during the mid-recrudescence phase. Each bar represents mean \pm S.E.M. $(n=4)$. Means bearing same superscripts do not differ from each other while bearing different superscripts are different from each other statistically at $P<0.05$ (Duncan's multiple range test). Superscripts A, $B, C$ and D are used for $17 \beta-H S D$ while $a, b, c$ and $d$ for $3 \beta-H S D$. The $F$ value after ANOVA of data related to $3 \beta$-HSD activity in ovarian fragments in response to L-NAME treatment was 27.413 while 20.303 for $17 \beta$-HSD. Similarly, $F$ values for $3 \beta$-HSD and $17 \beta-H S D$ activities in ovarian fragments after SNP treatment were 68.354 and 16.210 respectively.

late-quiescence phase. SNP treatment of recrudescing catfish stimulated remarkable ovarian development as evident from elevated GSI (Fig. 1B). SNP-treated ovary showed predominantly oocyte-III, whereas the perinucleolar and oocyte-I were drastically reduced as

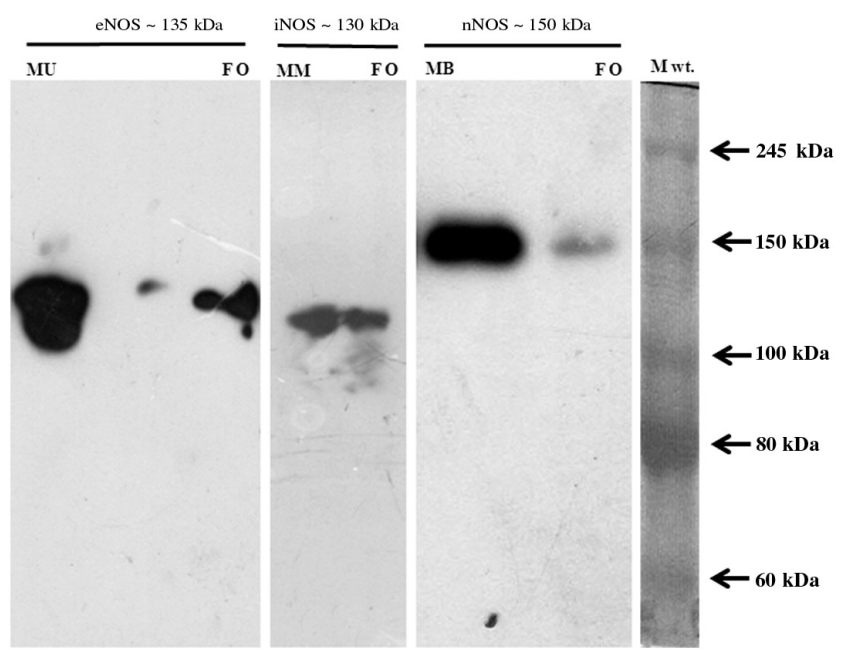

Figure 11 Immunoblots for validation of specificities of eNOS, iNOS and $\mathrm{nNOS}$ antibodies. Lane FO ovary of C. batrachus, lane MU-mice uterus, lane MM- mice macrophages, lane MB- mice brain and lane $\mathrm{M}$ wt.- molecular weight marker. 

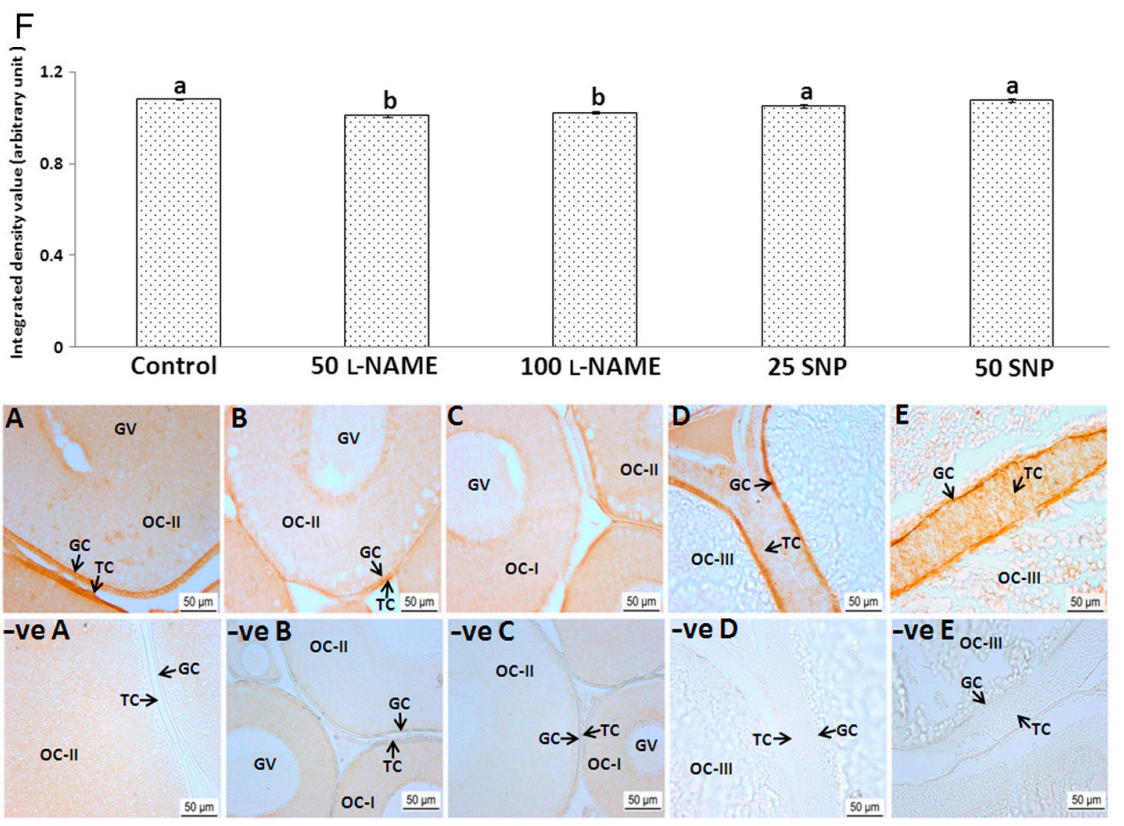

Figure 12 Expression of eNOS in the ovary of C. batrachus after treatments with different doses of L-NAME $(50 \mu \mathrm{g}$ and $100 \mu \mathrm{g})$ and SNP $(25 \mu \mathrm{g}$ and $50 \mu \mathrm{g}$ ) per $100 \mathrm{gb} . w \mathrm{t}$. during the mid-recrudescence phase. Figure $A$ represents control section while $B$ and $C$ represent L-NAME $(50 \mu \mathrm{g}$ and $100 \mu \mathrm{g})$-treated ovarian sections and D and E show SNP $(25 \mu \mathrm{g}$ and $50 \mu \mathrm{g})$ treated ovarian sections. - ve A to - ve E denote corresponding negative controls. Expression was quantified in term of integrated density value per unit area $\left(\mathrm{IDV} \times 10^{6}\right)$ and presented in figure F. Each bar represents mean \pm S.E.M. $(n=5)$. Means bearing same superscripts do not differ from each other while bearing different superscripts are different from each other statistically at $P<0.05$ (Duncan's multiple range test). The $F$ values after ANOVA of IDV was 26.193 in response to L-NAME treatment and 0.355 after SNP treatment. Note: Oocytes-I (OC-I), Oocytes-II (OC-II), OocytesIII (OC-III), Germinal vesicle (GV), Granulosa Cell (GC), Thecal Cell (TC).

compared to the control ovaries (Fig. 3d, D, e, E and F). On the contrary, treatment with L-NAME suppressed the ovarian development as was evident from the more oocyte-I and very less oocyte-II (Fig. 3b, B, C, C and F) as compared to control ovary (Fig. 3a, A and F). Oocyte-III was rarely observed in L-NAME-treated ovary (Fig. 3b, $\mathrm{B}, \mathrm{C}, \mathrm{C}$ and $\mathrm{F}$ ).

\section{Effects of SNP and L-NAME on circulating and ovarian vitellogenin}

Although vitellogenin level in the serum was unaltered, it was suppressed in the ovary by the higher dose of
L-NAME during the late quiescent phase (Fig. 4A). Treatment with high dose of SNP, however, resulted in the marginal rise in vitellogenin in serum and ovary, both. Low dose of SNP was ineffective in altering its level in serum and ovary (Fig. 4A). During the midrecrudescence phase, both the doses of L-NAME decreased the vitellogenin in the serum as well as ovary. Serum vitellogenin level was drastically suppressed (Fig. 4B). On the contrary, both the doses of SNP increased the vitellogenin in ovary tremendously, whereas its low dose failed to change its level in serum but increased it at high dose level (Fig. 4B).
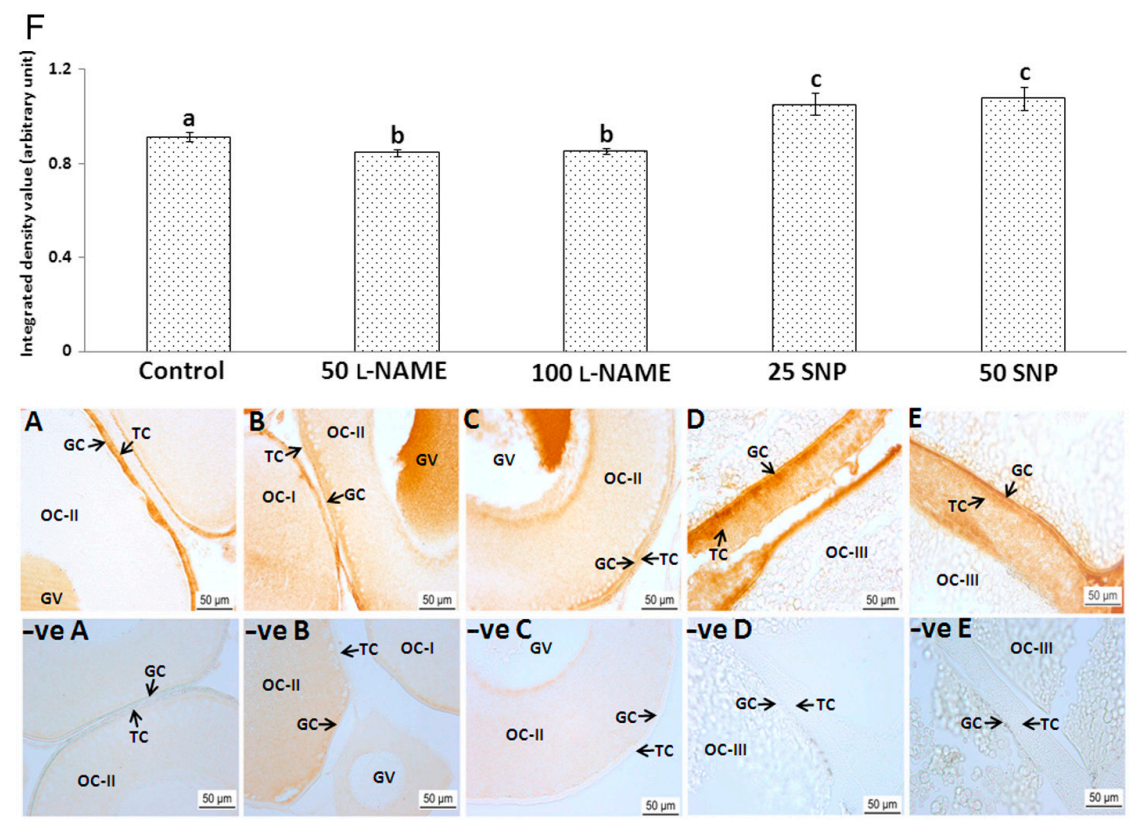

Figure 13 Expression of iNOS in the ovary of C. batrachus after treatments with different doses of L-NAME $(50 \mu \mathrm{g}$ and $100 \mu \mathrm{g})$ and SNP $(25 \mu \mathrm{g}$ and $50 \mu \mathrm{g})$ per $100 \mathrm{gb} . w t$. during the mid-recrudescence phase. Figure $A$ represents control section while $B$ and $C$ represent L-NAME $(50 \mu$ g and $100 \mu g)$-treated ovarian sections and D and E show SNP $(25 \mu \mathrm{g}$ and $50 \mu \mathrm{g})$-treated ovarian sections. -ve A to -ve E denote corresponding negative controls. Expression was quantified in term of integrated density value per unit area $\left(\mathrm{IDV} \times 10^{6}\right)$ and presented in figure $\mathrm{F}$. Each bar represents mean \pm S.E.M. $(n=5)$. Means bearing same superscripts do not differ from each other while bearing different superscripts are different from each other statistically at $P<0.05$ (Duncan's multiple range test). The $F$ values after ANOVA of IDV was 8.409 in response to L-NAME treatment and 7.769 after SNP treatment. Note: Oocytes-I (OC-I), Oocytes-II (OC-II), Oocytes-III (OC-III), Germinal vesicle (GV), Granulosa Cell (GC), Thecal Cell (TC). 


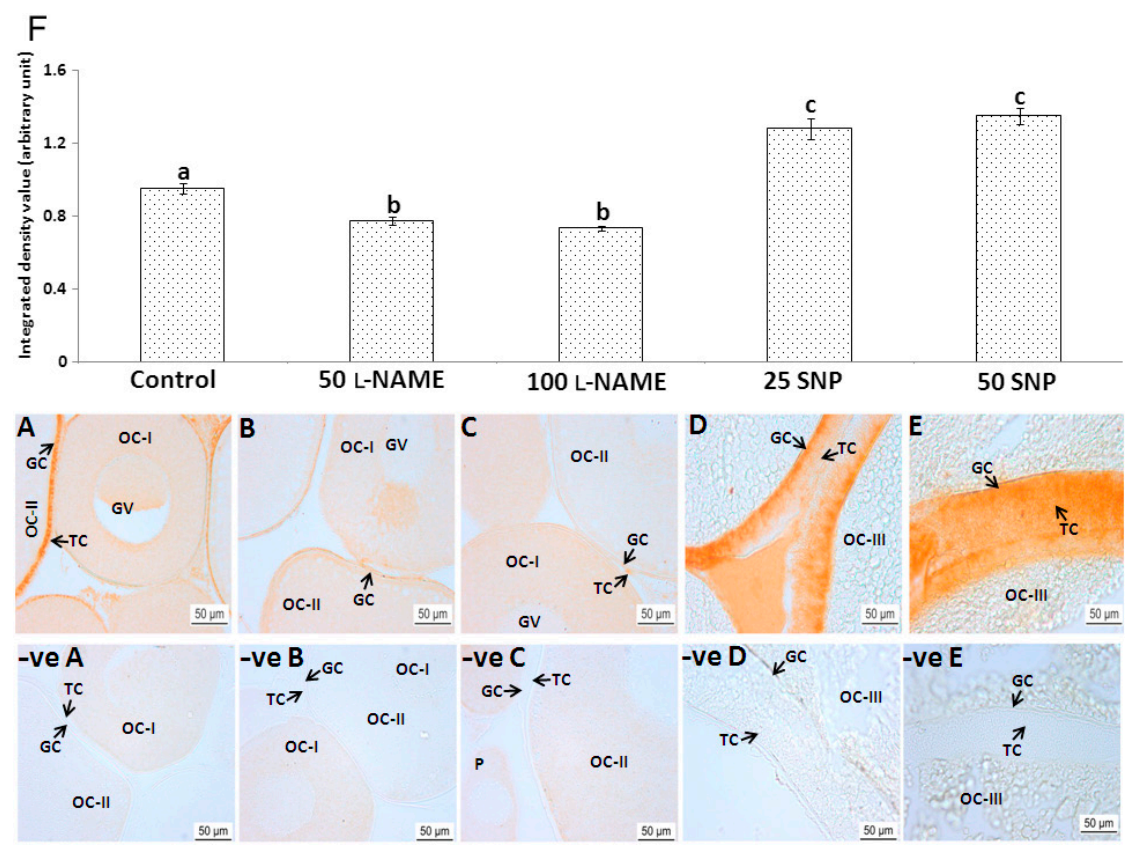

\begin{abstract}
Figure 14 Expression of nNOS in the ovary of C. batrachus following treatments with different doses of L-NAME $(50 \mu \mathrm{g}$ and $100 \mu \mathrm{g})$ and SNP $(10 \mu \mathrm{g}$ and $25 \mu \mathrm{g})$ per $100 \mathrm{~g}$ b.wt. during the mid-recrudescence phase. Figure $\mathrm{A}$ represents control section while $B$ and $C$ represent L-NAME $(50 \mu \mathrm{g}$ and $100 \mu \mathrm{g})$-treated ovarian sections and $\mathrm{D}$ and $\mathrm{E}$ show $\mathrm{SNP}$ $(25 \mu \mathrm{g}$ and $50 \mu \mathrm{g})$-treated ovarian sections. -ve A to -ve E denote corresponding negative controls. Expression are quantified in the term of integrated density value per unit area $\left(\right.$ IDV $\left.\times 10^{6}\right)$ and presented in figure F. Each bar represents mean \pm S.E.M. $(n=5)$. Means bearing same superscripts do not differ from each other while bearing different superscripts are different from each other statistically at $P<0.05$ (Duncan's multiple range test). The $F$ values after ANOVA of IDV was 48.290 in response to L-NAME treatment and 38.985 after SNP treatment. Note: Oocytes-I (OC-I), Oocytes-II (OC-II), Oocytes-III (OC-III), Germinal vesicle (GV), Granulosa Cell (GC), Thecal Cell (TC).
\end{abstract}

\section{In vivo effects of SNP and $L-N A M E$ on circulating and ovarian 17ß-estradiol, testosterone and total nitrate-nitrite}

During the late-quiescence phase, ovarian levels of $17 \beta$-estradiol, testosterone and $\mathrm{NO}$ were decreased by the higher dose of L-NAME (Fig. 5A), whereas SNP treatment elevated their levels in the ovary only at its higher dose (Fig. 5B). Similar effects of these NO-related compounds were observed on their serum levels too except that low dose of L-NAME also decreased NO and testosterone (Fig. 5C and D). However, during the mid-recrudescence phase, both the doses of L-NAME decreased and SNP markedly increased ovarian (Fig. 6A and B) and circulating (Fig. 6C and D) levels of $17 \beta$-estradiol, testosterone and NO.

\section{In vivo effects of SNP and $L-N A M E$ on the activities of $3 \beta-H S D$ and $17 \beta-H S D$ in ovary}

L-NAME treatment suppressed the activities of $3 \beta-\mathrm{HSD}$ and $17 \beta-\mathrm{HSD}$ in the ovary only at higher doses during the late-quiescence phase (Fig. 7A), but SNP increased their activities at its higher dose level (Fig. 7B). However, during mid-recrudescence phase, activities of these steroidogenic enzymes were decreased by L-NAME (Fig. 7C) and increased by SNP (Fig. 7D) respectively, at both their dose levels $(P<0.05)$.

\section{In vitro effects of SNP and L-NAME on 17/-estradiol, testosterone and total nitrate-nitrite in ovarian fragments and culture medium}

In the mid-recrudescence phase, all the three doses of L-NAME suppressed the ovarian levels of NO,
$17 \beta$-estradiol and testosterone in a dose-dependent manner in general (Fig. 8A). However, SNP treatment increased their levels; maximum increase was observed at $10^{-5} \mathrm{M} \mathrm{SNP}$ (Fig. $8 \mathrm{~B}$ ). Although $10^{-4} \mathrm{M}$ SNP raised the levels of $\mathrm{NO}, 17 \beta$-estradiol and testosterone in ovarian fragments in comparison to control but induction was less than the $10^{-5} \mathrm{M}$ SNP (Fig. 8B). The levels of NO and $17 \beta$-estradiol in the culture medium was also reduced by the L-NAME in dose-dependent manner (Fig. 9A). On the contrary, SNP treatments raised their levels in the culture Medium-199 (Fig. 9B). Moreover, testosterone was neither detected in the medium of control group nor in the treated ones.

\section{In vitro effects of $S N P$ and $L-N A M E$ on the activities of $3 \beta-H S D$ and $17 \beta-H S D$ in ovarian fragments}

The activities of these steroidogenic enzymes in the cultured ovarian fragments were decreased by the L-NAME in a dose-dependent manner during the mid-recrudescence phases (Fig. 10A). Although SNP treatment resulted in the significant increase in their activities in comparison to the control ovarian fragments except that SNP at low dose did not influence the activity of 17 $\beta-\mathrm{HSD}$ (Fig. 10B).

\section{Effects of SNP and L-NAME on expressions of different NOS in the ovary}

The immunoblots presented in Fig. 11 indicates clearly that the antibodies against different NOSs were highly specific, as evident from the single band in the catfish ovarian extract, corresponding to the appropriate molecular weight and the single band in mice tissue's extract lanes against respective antibody. 
After validation, antibodies of different NOSs were used for their immunolocalization in the catfish ovary.

During the mid-recrudescence phase, intense immunoreaction against eNOS antibody were detected in the theca and granulosa layer in the control and SNPtreated ovarian follicles (Fig. 12A, D, E and F), whereas L-NAME treatment reduced the immunoreaction against eNOS antibody (Fig. 12B, C and F). Immunoprecipitation against iNOS and nNOS antibodies were enhanced by the SNP and suppressed by the L-NAME in theca and granulosa cells in comparison to the controls (Figs 13A, $\mathrm{B}, \mathrm{C}, \mathrm{D}, \mathrm{E}, \mathrm{F}$ and $14 \mathrm{~A}, \mathrm{~B}, \mathrm{C}, \mathrm{D}, \mathrm{E}, \mathrm{F})$ respectively. Interestingly, an intense immunoprecipitation against iNOS was also observed in the germinal vesicle of oocyte-I and II of the control as well as L-NAME-treated catfish ovary (Fig. 13A, B and C).

\section{Discussion}

Findings of the present study clearly suggest that NO stimulates ovarian folliculogenesis and steroidogenesis in fish. The effectiveness of ovarian stimulatory action of NO depends on the follicular status in fish ovary and concentration of NO. Study also reveals that NO regulates NOS expression in the ovary.

The study indicates that NO promotes follicular growth and maturation in fish ovary as evident from the increased GSI and substantially high number of advanced oocytes, particularly oocytes III, in SNPtreated catfish compared to control fish ovary. L-NAME treatment rather suppressed ovarian development as shown by the decreased GSI and relatively no advance oocytes in ovary. Manwar and coworkers (2006) have also reported that $\mathrm{NO}$ promotes ovarian function in a bird Japanese quail, Coturnix coturnix japonica and have shown that high level of ovarian NO is associated with high egg production. However, they have not provided any basis for the NO-stimulated folliculogenesis in Japanese quail. In mammals also, a positive correlation between ovarian $\mathrm{NO}$ and growing follicles has been reported (Rosselli et al. 1998, Kumar et al. 2012). In fact, NO is established as one of the several intraovarian regulators of folliculogenesis (Rosselli et al. 1998, Mitsube et al. 2002, Goud et al. 2005, Skarzynski et al. 2005). Matsumi and coworkers (2000) have observed an association between developmental status of immature follicles (either into development or atresia) and iNOS level in granulosa cells. El-Sherry et al. (2013) has reported high NO level in ovary concomitant with increase in follicular diameter in ewes.

The follicular growth and development in fishes are largely due to the accumulation of vitellogeninderived yolk proteins, which is critical in determining the egg quality and reproductive success (Maitra et al. 2007). Vitellogenin, a glycolipophosphoprotein, is synthesized in the liver under the influence of $17 \beta$-estradiol and secreted into the blood from where it is sequestered by the growing oocytes through receptor-mediated mechanism under hormonal control. Circulating vitellogenin was significantly high in SNP-treated catfish. Vitellogenin-derived complex protein was also remarkably increased in the ovary. On the contrary, L-NAME decreased it in serum and ovary drastically. Folliculogenic role of NO has been reported earlier in oviparous quail, but no explanation has been provided. However, the present study for the first time provides direct evidence that $\mathrm{NO}$ induces vitellogenin synthesis and its uptake by the oocytes in fish. It is likely that the NO-induced $17 \beta$-estradiol in C. batrachus might have stimulated vitellogenesis. As $\mathrm{NO}$ is known to stimulate the release of gonadotropins, it is possible that NO might have promoted the incorporation of vitellogenin in growing oocytes and depositing it as yolk proteins (Maitra et al. 2007, Nath et al. 2007) by stimulating the release of gonadotropins. The massive increase in yolk granules in highly advanced oocytes in the SNP-treated catfish ovary and occasional appearance of such yolk granules in L-NAME-treated ovary support this notion.

$\mathrm{NO}$ also seems to promote the growth and development of follicular layer as a distinct growth in the follicular layer of the follicles in SNP-treated ovary was observed than that of the follicular layer of follicles in the control and L-NAME-treated ovary. The increased steroidogenic activity after SNP treatments indicates the possibilities of NO-induced hypertrophy in steroidogenic cells, i.e., granulosa cells and special thecal cells. Authors have already reported the seasonal pattern of growth of oocytes in this catfish, Clarias batrachus (Singh \& Lal 2015), wherein a reproductive phase-dependent gradual growth in follicular layer is depicted and therein follicular layer of the highly advanced follicles is quite thick in comparison to the less-developed follicles. In fact, in highly advanced ovarian follicles in fishes, the follicular cells are highly hypertrophied; the granulosa cells form single layer around oocytes and thecal cells are arranged in multiple layers around the granulosa cells having a basement membrane between granulosa and thecal cells (Hoar \& Nagahama 1978).

Activation of $3 \beta-\mathrm{HSD}$ and $17 \beta-\mathrm{HSD}$ enzymes in catfish ovary with concomitant increase in circulating and ovarian $17 \beta$-estradiol and testosterone concentrations after SNP treatment distinctly indicate that NO stimulates ovarian steroidogenesis. This notion is further substantiated by the fact that L-NAME suppressed the activities of these enzymes and simultaneously declined the levels of $17 \beta$-estradiol and testosterone in serum and ovary in C. batrachus. Authors have recently reported the expression of nNOS, eNOS and iNOS predominantly in the thecal and granulosa cells of the growing follicles, and positive correlation between ovarian $\mathrm{NO}$ and $17 \beta$-estradiol with growing follicular size, suggesting an involvement of $\mathrm{NO}$ in 
ovarian steroidogenesis (Singh \& Lal 2015). However, these findings are in marked contrast to most of the earlier studies, which reveal NO-induced inhibition in ovarian steroidogenesis.

In fact, a number of studies have been carried to examine the role of $\mathrm{NO}$ in ovarian steroidogenesis in mammals; however, results are highly inconsistent. Studies suggest that NO exerts anti-steroidogenic effects in rat (Dave et al. 1997), human (Van Voorhis et al. 1994, Rosselli et al. 1998), porcine (Matsumi et al. 2000, Ponderato et al. 2000, Grasselli et al. 2001) and bovine (Basini \& Tamanini 2000). Jablonka-Shariff and Olson (1998) observed many-fold increase in estradiol and no change in progesterone concentration in eNOS-knockout mice as compared to control mice. Mitsube and coworkers (1999) have noticed no effect of L-NMMA (a NOS inhibitor) on LH-stimulated steroidogenesis ex vivo perfused preovulatory rat ovary, but spermine NONOate (an NO donor) stimulated progesterone production. Treatment of PMSG primed rat ovary with NO donor promoted progesterone production in a dose-dependent manner but suppressed the estradiol secretion concomitantly (Dong et al. 1999). Bonello and coworkers (1996) noticed a decreased $17 \beta$-estradiol secretion in rats after ovarian perfusion with L-NAME (a NOS inhibitor) and suggested that $\mathrm{NO}$ may positively regulate $17 \beta$-estradiol synthesis. Faes and coworkers (2009) have reported a biphasic effect of $\mathrm{NO}$ on $17 \beta$-estradiol secretion by antral granulosa cells of cow in vitro; higher dose of SNP $\left(10^{-3} \mathrm{M}\right)$ decreases and low dose $\left(10^{-5} \mathrm{M}\right)$ increases $17 \beta$-estradiol secretion. The mode and mechanisms that are proposed to explain the negative effects of $\mathrm{NO}$ on ovarian steroid production are also varied. Some studies suggest the involvement of $\mathrm{NO} / \mathrm{cGMP}$ pathway in inhibition of steroidogenesis in rats (Ellman et al. 1993) and pigs (Grasselli et al. 2001). Basini and coworkers (2000), however, have suggested that the anti-steroidogenic action of $\mathrm{NO}$ is CGMP independent and is possibly mediated through inhibition of cytochrome P450 aromatase (Van Voorhis et al. 1994). Kagabu and coworkers (1999) have reported NO-induced reduction in aromatase mRNA.

In vitro findings on steroidogenic parameters in the present study further support the steroidogenic role of NO. They also suggest that NO stimulates steroidogenesis by directly acting at ovarian level, though under in vivo condition, its action through hypothalmo-hypophyseal axis cannot be ruled out. It may be suggested that exogenous NO might be stimulating steroid production, at least in part, by augmenting the release of $\mathrm{GnRH}$ and gonadotropins by acting at hypothalamo-hypophyseal level. This suggestion is proposed based on some earlier reports wherein $\mathrm{NO}$ is shown to release the $\mathrm{GnRH}$ and gonadotropins (Kumar et al. 2012). NO is known to release gonadotropins from pituitary by stimulating $\mathrm{GnRH}$ secretion from hypothalamus through the activation of heme-containing guanylate cyclase and neuropeptide $Y$ (Bonavera et al. 1996). $\mathrm{NO}$ is also reported to decrease brain dopamine (Lorrain \& Hull 1993), a strong gonadotropin-release inhibitor in most fishes. SNP might have increased the secretion of gonadotropin in the catfish by decreasing the dopamine. $\mathrm{NO}$ might also have activated $3 \beta-\mathrm{HSD}$ and $17 \beta-\mathrm{HSD}$ enzymes to enhance the sex steroid production.

The expressions of all NOS isoforms were enhanced by SNP and reduced by L-NAME suggesting thereby that NO may regulate NOS expression in ovary through feedback mechanism. This positive feedback control of eNOS, iNOS and nNOS expressions in fish may be similar to the recent report by Lee and Choy (2013) who have shown that NO augments iNOS expression in human lung epithelial cell line (A549) through S-nitrosylation of Ras and activation of PI3K and mTOR. Yuhanna and coworkers (1999) have also demonstrated the positive feedback control mechanism of eNOS expression by NO in human lung. Some studies, however, have reported negative feedback control of NOS expressions by NO; iNOS-derived NO downregulates iNOS expression in mouse cells (Griscavage et al. 1993, Hinz et al. 2000). Similarly, NO is also known to inhibit the expressions of eNOS (Grumbach et al. 2005) and nNOS in rat forebrain (De Alba et al. 1999). Though it is suggested that NO may use varieties of mode and mechanism to exert these feedback control on NOS expressions (Griscavage et al. 1993, De Alba et al. 1999, Yuhanna et al. 1999, Hinz et al. 2000, Lee \& Choy 2013), no study has been carried out so far to examine that how these feedback regulation of NOS expression by NO is terminated. The experimental design of the present study does not permit us to comment on this aspect, however, considering the wide-ranging biological actions of $\mathrm{NO}$ in tissuespecific manner, it may be proposed that perhaps the redox status and concentration of $\mathrm{NO}$ of the target cells, bestowed with specific cellular machinery and molecular ambience, altogether may decide the type of feedback effect of $\mathrm{NO}$ on the NOS expressions and their termination.

Finally, it can be summarized that chemical (exogenous $\mathrm{NO}$ donor) as well as biological (ovary-derived) NO promotes the follicular growth and development in the oviparous lower vertebrates by augmenting vitellogenesis and its uptake by ovarian follicles. It also stimulates the ovarian steroidogenesis. To the best of author's knowledge, this is the first report in fish. Effectiveness of $\mathrm{NO}$ actions seems to be reproductive status dependent; $\mathrm{NO}$ exerts more pronounced effects in fish, which has already begun the ovarian activities. The folliculogenic and steroidogenic action of $\mathrm{NO}$ appears to be mediated partly through NO-induced $\mathrm{GnRH}$ and gonadotropins secretions. However, other mode and mechanisms of $\mathrm{NO}$ action cannot be ruled out. The regulation of expressions of NOS by NO is also a noteworthy finding. 


\section{Declaration of interest}

The authors declare that there is no conflict of interest that could be perceived as prejudicing the impartiality of the research reported.

\section{Funding}

This work was supported by University Grants Commission, New Delhi, India (grant number 39-584/2010 (SR)).

\section{Acknowledgement}

Authors are grateful to Prof P Nath, Viswa Bharati, Santiniketan, India, for providing all facilities to measure vitellogenin.

\section{References}

Basini G \& Tamanini C 2000 Selenium stimulates estradiol production in bovine granulosa cells: Possible involvement of nitric oxide. Domestic Animal Endocrinology 18 1-17. (doi:10.1016/S0739-7240(99)00059-4)

Basini G, Grasselli F, Ponderato N, Bussolati S \& Tamanini C 2000 Lipid hydroperoxide and CGMP are not involved in nitric oxide inhibition of steroidogenesis in bovine granulosa cells. Reproduction Fertility and Development 12 289-295. (doi:10.1071/RD00089)

Bonavera JJ, Kalra P \& Kalra S 1996 L-Arginine/nitric oxide amplifies the magnitude and duration of the luteinizing hormone surge induced by estrogen: involvement of neuropeptide Y. Endocrinology 137 1956-1962. (doi:10.1210/en.137.5.1956)

Bonello N, McKie K, Jasper M, Andrew L, Ross N, Braybon E, Brannstrom M \& Norman RJ 1996 Inhibition of nitric oxide: effects on interleukin-1 enhanced ovulation rate, steroid hormones, and ovarian leukocyte distribution at ovulation in the rat. Biology of Reproduction 54 436-445. (doi:10.1095/biolreprod54.2.436)

Dave S, Farrance DP \& Whitehead SA 1997 Evidence that nitric oxide inhibits steroidogenesis in cultured rat granulosa cells. Clinical Science 92 277-284. (doi:10.1042/cs0920277)

De Alba J, Cárdenas A, Moro MA, Leza JC, Lorenzo P, Boscá L \& Lizasoain I 1999 Down-regulation of neuronal nitric oxide synthase by nitric oxide after oxygen-glucose deprivation in rat forebrain slices. Journal of Neurochemistry 72 248-254. (doi:10.1046/j.14714159.1999.0720248.x)

Dong YL, Gangula PR, Fang L \& Yallampalli C 1999 Nitric oxide reverse prostaglandin-induced inhibition in ovarian progesterone secretion in rats. Human Reproduction 14 27-32. (doi:10.1093/humrep/14.1.27)

Dubey PK \& Sharma GT 2016 Nitric oxide and ovarian folliculogenesis: a possible role in follicular atresia. Asian Australasian Journal of Animal Sciences In Press. (doi:10.5713/ajas.15.0831)

Ellman C, Corbett JA, Misko TP, McDaniel M \& Beckerman KP 1993 Nitric oxide mediates interleukin-1-induced cellular cytotoxicity in rat ovary: potential role for nitric oxide in the ovulatory process. Journal of Clinical Investigation 92 3053-3056. (doi:10.1172/JCI116930)

EI-Sherry TM, Sensory W, Mahmoud GB \& Wasfy SI 2013 Effect of dinoprost and cloprostenol on serum nitric oxide and corpus luteum blood flow during luteolysis in ewes. Theriogenology 80 513-518. (doi:10.1016/j. theriogenology.2013.05.007)

Faes MR, Caldas-Bussiere MC, Viana KS, Dias BL, Costa FR \& Escocard RM 2009 Nitric oxide regulates steroid synthesis by bovine antral granulosa cells in a chemically defined medium. Animal Reproduction Science 110 222-236. (doi:10.1016/j.anireprosci.2008.01.018)

Goud AP, Goud PT, Diamond MP \& Abu-Soud HM 2005 Nitric oxide delays oocyte aging. Biochemistry 44 11361-11368. (doi:10.1021/bi050711f)

Grasselli F, Ponderato N, Basini G \& Tamanini C 2001 Nitric oxide synthase expression and nitric oxide/cyclic GMP pathway in swine granulosa cells. Domestic Animal Endocrinology 20 241-252. (doi:10.1016/ S0739-7240(01)00096-0)

Grazul-Bilska AT, Navanukraw C, Johnson ML, Arnold DA, Reynolds LP \& Redmer DA 2006 Expression of endothelial nitric oxide synthase in the ovine ovary throughout the estrous cycle. Reproduction 132 579-587. (doi:10.1530/REP-06-0009)

Griscavage JM, Rogers NE, Sherman MP \& Ignarro LJ 1993 Inducible nitric oxide synthase from a rat alveolar macrophage cell line is inhibited by nitric oxide. Journal of Immunology 151 6329-6337.

Grumbach IM, Chen W, Mertens SA \& Harrison DG 2005 A negative feedback mechanism involving nitric oxide and nuclear factor $\mathrm{\kappa}$ B modulates endothelial nitric oxide synthase transcription. Journal of Molecular and Cellular Cardiology 39 595-603. (doi:10.1016/j. yjmcc.2005.06.012)

Hinz B, Brune K \& Pahl A 2000 Nitric oxide inhibits inducible nitric oxide synthase mRNA expression in RAW 264.7 macrophages. Biochemical and Biophysical Research Communications 271 353-357. (doi:10.1006/ bbrc.2000.2632)

Hoar WS \& Nagahama Y 1978 The cellular sources of sex steroids in teleost gonads. Annales de Biologie Animale Biochimie Biophysique 18 893-898. (doi:10.1051/rnd:19780521)

Jablonka-Shariff A \& Olson LM 1998 The role of nitric oxide in oocyte meiotic maturation and ovulation: meiotic abnormalities of endothelial nitric oxide synthase knock out mouse oocytes. Endocrinology 139 2944-2954. (doi:10.1210/en.139.6.2944)

Jablonka-Shariff A \& Olson LM 1997 Hormonal regulation of nitric oxide synthases and their cell-specific expression during follicular development in the rat ovary. Endocrinology 138 460-468. (doi:10.1210/ en.138.1.460)

Jarabak J 1969 Soluble 17ß-hydroxysteroid dehydrogenase of human placenta. In The Methods in Enzymology, edn 15, pp 746-752. Steroid and Terpenoids. Ed RB Clayton. New York/London: Academic Press.

Kagabu S, Kodama H, Fukuda J, Karube A, Murata M \& Tanaka T 1999 Inhibitory effects of nitric oxide on the expression and activity of aromatase in human granulosa cells. Molecular Human Reproduction 55 396-401. (doi:10.1093/molehr/5.5.396)

Kim H, Moon C, Ahn M, Lee Y, Kim H, Kim S, Ha T, Jee Y \& Shin T 2005 Expression of nitric oxide synthase isoforms in the porcine ovary during follicular development. Journal of Vacuum Science 6 97-101.

Kranzfelder D, Reich R, Abisogun O \& Tsafriri A 1992 Preovulatory changes in the perifollicular capillary network in the rat: role of eicosanoids. Biology of Reproduction 46 379-385. (doi:10.1095/biolreprod46.3.379)

Kumar A, Dangi SS, Mahla A S, Rajoriya JS \& Purohit GN 2012 Role of nitric oxide in animal reproduction: a review. Theriogenology Insight 2 137-144.

Lal B 2014 Some non-classical intragonadal regulators of fish reproduction. In The Sexual Plasticity and Gametogenesis in Fishes, pp 236-249. Ed B Senthilkumaran. New York, NY, USA: Nova Science Publishers Inc.

Lee M \& Choy JC 2013 Positive feedback regulation of human inducible nitric-oxide synthase expression by Ras protein S-nitrosylation. Journal of Biological Chemistry 288 15677-15686. (doi:10.1074/jbc. M113.475319)

Lorrain DS \& Hull EM 1993 Nitric oxide decreases dopamine and serotonin release in the medial preoptic area. Neuroreport 5 87-89. (doi:10.1097/00001756-199310000-00024)

Maitra S, Sahu R, Trehan N, Garg SK \& Nath P 2007 Circannual variation in plasma vitellogenin and gonadotropin II levels in relation to annual ovarian cycle in female mrigal, Cirrhinus mrigala. Aquaculture 265 370-384. (doi:10.1016/j.aquaculture.2007.02.002)

Manwar SJ, Moudgal RP, Sastry KVH, Mohan J, Tyagi JB \& Raina R 2006 Role of nitric oxide in ovarian follicular development and egg production in Japanese quail, Coturnix coturnix japonica. Theriogenology 65 1392-1400. (doi:10.1016/j.theriogenology.2005.08.023)

Matsumi H, Yano T, Osuga Y, Kugu K, Tang X, Xu JP, Yano N, Kurashima Y, Ogura T, Tsutsumi $\mathbf{O}$ et al. 2000 Regulation of nitric oxide synthase to promote cytostasis in ovarian follicular development. Biology of Reproduction 63 141-146. (doi:10.1095/biolreprod63.1.141)

Maul H, Longo M, Saade GR \& Garfield RE 2003 Nitric oxide and its role during pregnancy: from ovulation to delivery. Current Pharmaceutical Design 9 359-380. (doi:10.2174/1381612033391784)

Miranda KM, Espey MG \& Wink DA 2001 A rapid, simple spectrophotometric method for simultaneous detection of nitrate and nitrite. Nitric Oxide 51 62-71. (doi:10.1006/niox.2000.0319)

Mitchell LM, Kennedy CR \& Hartshorne GM 2004 Expression of nitric oxide synthase and effect of substrate manipulation of the nitric oxide pathway in mouse ovarian follicles. Human Reproduction 19 30-40. (doi:10.1093/humrep/deh032) 
Mitsube K, Mikuni M, Matousek M \& Brannstrom M 1999 Effect of a nitric oxide donor and nitric oxide synthase inhibitors on luteinizing hormone induced ovulation in the ex-vivo perfused rat ovary. Human Reproduction 14 2537-2543. (doi:10.1093/humrep/14.10.2537)

Mitsube K, Zackrisson U \& Brannstrom M 2002 Nitric oxide regulates ovarian blood flow in the rat during the periovulatory period. Human Reproduction 17 2509-2516. (doi:10.1093/humrep/17.10.2509)

Mukrakami T, Ikebuchi Y, Ohtsuka A, Taguchi T \& Ohtani O 1988 The blood vascular wreath of rat ovarian follicle, with special reference to its changes in ovulation and luteinisation: a scanning electron microscopic study of corrosion casts. Archives of Histology and Cytology $\mathbf{5 1}$ 299-313. (doi:10.1679/aohc.51.299)

Nath P \& Maitra S 2001 Role of two plasma vitellogenins from Indian major carp, Cirrhinus mrigala in catfish, Clarias batrachus vitellogenesis. General and Comparative Endocrinology 124 30-44. (doi:10.1006/ gcen.2001.7686)

Nath P, Sahu R, Kavita SK\& Bhattacharya D 2007 Vitellogenesis with special emphasis on Indian fishes. Fish Physiology and Biochemistry 33 359-366. (doi:10.1007/s10695-007-9167-0)

nee Pathak ND \& Lal B 2010 Seasonality in expression and distribution of nitric oxide synthase isoforms in the testis of the catfish, Clarias batrachus: role of nitric oxide in testosterone production. Comparative Biochemistry and Physiology 151 286-293. (doi:10.1016/j.cbpc.2009.11.008)

Nishikimi A, Matsukawa T, Hoshino K, Ikeda S, Kira Y, Sato EF, Inoue M \& Yamada M 2001 Localization of nitric oxide synthase activity in unfertilized oocytes and fertilized embryos during pre-implantation development in mice. Reproduction 122 957-963. (doi:10.1530/ rep.0.1220957)

Ponderato N, Grasselli F, Saleri R \& Tamanini C 2000 Factors modulating apoptosis: An in vitro study in swine granulosa cells. Reproduction in Domestic Animals 35 213-219. (doi:10.1046/j.14390531.2000.00217.x)

Reynolds LP, Grazul-Bilska AT \& Redmer DA 2002 Angiogenesis in the female reproductive system: pathological implications. International Journal of Experimental Pathology 83 151-164. (doi:10.1046/j.13652613.2002.00277.x)

Rosselli M, Keller PJ \& Dubey RK 1998 Role of nitric oxide in the biology, physiology and pathophysiology of reproduction. Human Reproduction Update 4 3-24. (doi:10.1093/humupd/4.1.3)

Singh S \& Singh TP 1985 Kinetic studies on the enzymes involved in estrogen biosynthesis and evidence for existence of a single 5-ene-3 $\beta$ hydroxysteroids dehydrogenase complex in the ovary of a freshwater catfish, Clarais batrachus. General and Comparative Endocrinology 58 458-463. (doi:10.1016/0016-6480(85)90119-4)

Singh VK \& Lal B 2015 Immunolocalization of nitric oxide synthase (NOS) isoforms in ovarian follicles of the catfish, Clarias batrachus and its relation with ovarian activity. General and Comparative Endocrinology 220 98-102. (doi:10.1016/j.ygcen.2014.04.001)
Skarzynski DJ, Jaroszewski JJ \& Okuda K 2005 Role of tumour necrosis factor- $\alpha$ and nitric oxide in luteolysis in cattle. Domestic Animal Endocrinology 28 340-346. (doi:10.1016/j.domaniend.2005.02.005)

Sundararaj BI \& Sehgal A 1970 Effects of a long or an increasing photoperiod on the initiation of ovarian recrudescence during the preparatory period in the catfish, Heteropneustes fossilis (Bloch.). Biology of Reproduction 2 413-424. (doi:10.1095/biolreprod2.3.413)

Tamanini C, Basin G, Grasselli F \& Tirelli M 2003 Nitric oxide and the ovary. Journal of Animal Science 81 1-7.

Tao Y, Fu Z, Zhang M, Xia G, Yang J \& Xie H 2004 Immunohistochemical localization of inducible and endothelial nitric oxide synthase in porcine ovaries and effects of $\mathrm{NO}$ on antrum formation and oocyte meiotic maturation. Molecular and Cellular Endocrinology 222 93-103. (doi:10.1016/j.mce.2004.04.014)

Tesone M, Abramovich D, Irusta G \& Parvorell F 2009 'Autocrine and paracrine regulation of the ovary'. In Reproductive Endocrinology: A Molecular Approach, pp 241-248. Ed PJ Chedrese. London, UK: Springer Science Business Media LLC.

Tripathi V \& Krishna A 2008 Changes in nitric oxide (NO) synthase isoforms and $\mathrm{NO}$ in the ovary of Heteropneustes fossilis (Bloch.) during the reproductive cycle. Journal of Endocrinology 199 307-316. (doi:10.1677/JOE-07-0509)

Van Voorhis BJ, Dunn MS, Snyder GD \& Weiner CP, 1994 Nitric oxide: an autocrine regulator of human granulosa-luteal cell steroidogenesis. Endocrinology 135 1799-1806. (doi:10.1210/en.135.5.1799)

Wiebe JP 1976 Steroidogenesis in rat Leydig Cells: changes in activity of 5 -ane and 5 -ene $3 \beta$-hydroxysteroid dehydrogenases during sexual maturation. Endocrinology 98 505-513. (doi:10.1210/endo-98-2-505)

Yamagata Y, Nakamura Y, Sugino N, Harada A, Takayama H, Kashida S \& Kato H 2002 Alterations in nitrate/nitrite and nitric oxide synthase in preovulatory follicles in gonadotropin-primed immature rat. Journal of Endocrinology 49 219-226. (doi:10.1507/endocrj.49.219)

Yuhanna IS, Mac Ritchie AN, Lantin-Hermoso RL, Wells LB \& Shaul PW 1999 Nitric oxide (NO) upregulates NO synthase expression in fetal intrapulmonary artery endothelial cells. American Journal of Respiratory Cell and Molecular Biology 21 629-636. (doi:10.1165/ajrcmb.21.5.3749)

Zackrisson U, Mikuni M, Wallin A, Delbro D, Hedin L \& Brannstrom M 1996 Cell-specific localization of nitric oxide synthases (NOS) in the rat ovary during follicular development, ovulation and luteal formation. Human Reproduction 11 2667-2673. (doi:10.1093/oxfordjournals. humrep.a019189)

Received 31 August 2016

First decision 11 October 2016

Revised manuscript received 31 October 2016

Accepted 4 November 2016 